\title{
Comparative Evaluation of the EIA Systems in Kenya, Tanzania, Mozambique, South Africa, Angola, and the European Union
}

\author{
Cristina Rebelo, José Guerreiro* \\ Faculdade de Ciências de Lisboa, Edifício TECLABS, Lisboa, Portugal \\ Email: cmrebelo@fc.ul.pt, „jasilva@fc.ul.pt, „joseguerreiro2958@gmail.com
}

How to cite this paper: Rebelo, C. and Guerreiro, J. (2017) Comparative Evaluation of the EIA Systems in Kenya, Tanzania, Mozambique, South Africa, Angola, and the European Union. Journal of Environmental Protection, 8, 603-636. https://doi.org/10.4236/jep.2017.85040

Received: March 13, 2017

Accepted: May 24, 2017

Published: May 27, 2017

Copyright ( 2017 by authors and Scientific Research Publishing Inc. This work is licensed under the Creative Commons Attribution International License (CC BY 4.0).

http://creativecommons.org/licenses/by/4.0/ (c) (i) Open Access

\begin{abstract}
This article provides a comparative overview of environmental impact assessment (EIA) in Mozambique, Tanzania, Kenya, South Africa, Angola, and the European Union (EU). EIA "systemic measure" and "foundation measure" criteria are used to evaluate and compare the performance of each system. In contrast to the EU, EIA must be carried out by registered experts in the African countries. In Tanzania, Mozambique and South Africa public consultation is mandatory during scoping. In Kenya and Tanzania the EIA study should contain measures to prevent health hazards, to ensure employee safety, and for emergency management. EIA system monitoring is required in Kenya, Tanzania, Mozambique, and in the EU, but not in South Africa and Angola. Financial issues, insufficient qualified personnel, and an increasing number of EIA applications undermine the capacity of competent authorities to adequately monitor these EIA systems. Consequently, training programmes increase effectiveness of EIA implementation is a common request. The African countries reviewed here have adopted EIA and integrated EIA systems into public policy despite the constraints they face. As they continue to gain experience in EIA and to revise their EIA systems, they are moving towards a more flexible system with greater public involvement and robust arrangements and practices.
\end{abstract}

\section{Keywords}

Environmental Impact Assessment (EIA), EIA Procedures, EIA Contents, EIA Evaluation Criteria 


\section{Introduction ${ }^{1}$}

The United Nations Conference on the Human Environment (Stockholm, 1972), the United Nations Conference on Environment and Development (Rio de Janeiro, 1992), and the World Summit on Sustainable Development (Johannesburg, 2002) laid a solid foundation and high-level commitment for integrating environment protection and economic development to achieve sustainable development [1]. These instruments introduced to integrate principles such as rational and integrated planning, and participatory economic and social analysis into public policy. Further they underscored the importance of capacity building in evaluation of environmental impacts of development projects. Together, they endorse the institutionalization of environmental impact assessment (EIA) at the national level in the decision-making process for proposed activities likely to have significant adverse environmental impacts.

At the national level, EIA was first formally introduced in the United States with the 1969 National Environmental Policy Act. Subsequently, other industrialized countries rapidly adopted EIA regulations. Today, more than 100 countries and all development banks and most international agencies require EIAs for major activities and projects.

EIA is a key instrument of European Union (EU) environmental policy. The Directive on the Assessment of the Effects of Certain Public and Private Projects on the Environment (EU EIA Directive), enacted in 1985 (85/337/EEC) [2], was amended through Directive 97/11/EC [3]. EIA practice and laws have been significantly improved since Directive 85/337/EEC came into effect.

In Africa, legal requirements or general procedures for EIA have evolved substantially over the past decade. Kenya, Tanzania, Mozambique, South Africa, and Angola each have adopted an EIA regulatory regime. The current challenge is to upgrade the EIA process and practice to tackle environmental decline that is grounded in poverty, underdevelopment, and lack of basic infrastructures. In an increasingly globalized world, democratization, deregulation, privatization, and decentralization also need to be incorporated into the public policy process. As a result, EIA arrangements need to become more flexible, less reliant on "command and control" measures, and open to greater public and stakeholder involvement [4]. At the same time, these countries, like many other developing

\footnotetext{
${ }^{1}$ EAP: Environmental Assessment Practitioner

EIA: Environmental Impact Assessment

EIM: Integrated Environmental Management

EIR: Environmental Impact Report

EMCA: Environmental Management and Coordination Act (Kenya)

EMP: Environmental Management Plan

EPDA: Environmental Pre-viability and Definition of Scope

EU: European Union

MICOA: Ministry for Environment Coordination (Mozambique)

NEMA: National Environmental Management Authority

NEMC: National Environmental Management Council (Tanzania)

SEA: Strategic Environmental Assessment

SER: Simplified Environmental Impact Report

ToR: Terms of Reference
} 
countries, face financial, structural, and resource constraints in introducing and instituting EIA arrangements.

This paper provides a comparative overview of EIA systems and practices in Kenya, Tanzania, Mozambique, South Africa, Angola, and the EU in order to assess their effectiveness ${ }^{2}$. The following issues will be addressed: What institutional frameworks exist? Which EIA procedures are followed? What are the details of EIA requirements? Is there a pattern of procedural arrangements for an EIA and its contents? Are the implemented EIA systems effective? What are the main constraints and gaps for genuine effectiveness of EIA systems? What are the next steps to improve the effectiveness of EIA systems and practice in these countries? An overview of the research methodology is provided, as well as a detailed comparative review of different "systemic measures" and "foundation measures" of these EIA systems.

\section{Methodology}

A two-step methodology was used in this research. First, a preliminary assessment of the EIA systems was carried out in the selected countries (Kenya, Tanzania, Mozambique, South Africa and Angola) ${ }^{3}$ through evaluation of their legal, institutional and procedural frameworks. Second, specific analytic criteria were used to compare the EIA systems in the five African countries and in the EU. The criteria applied in this study are based on those proposed by Ahmad Balsam and Christopher Wood [5], Wood [6] and Leu et al. [7], which are classified under two categories: systemic measures and foundation measures. The systemic measures are divided into three major categories: legal framework, administration framework and EIA procedures. The foundation measures accesses the existence of: 1) general guidelines issued by the national EIA authority, 2) regulation regarding which entities are able to carry out EIA studies; 3 ) training programs on EIA assessment and procedures.

This study is primarily based on descriptive criteria, formal EIA requirements and practical application methods. It considers the legal, institutional and procedures contexts of each EIA system and proceeds to a detailed comparison of the following EIA system attributes:

- legislative and administrative procedures for EIA

- aspects of EIA such as screening, scoping, EIA report review, mitigation, etc.

- measures undertaken to improve the effectiveness of EIA systems

The first two of these attributes broadly correspond to "systemic measures"

${ }^{2}$ This study was carried out within the EU-funded project PUMPSEA: Peri-urban mangrove forests as filters and potential phytoremediators of domestic sewage in East Africa. EU Contract no. 510863. This project's overall goal was to demonstrate that peri-urban mangroves are an ecological and economic means of mitigating coastal pollution through sewage filtration and offer an innovative set-up and management solution. The project developed technology for using constructed mangrove wetlands for the secondary treatment of domestic sewage water. One of the project's objectives was to develop an Environmental Impact Study on the use of mangrove wetlands for sewage filtration through procedures similar to those of the EU EIA Directive and in accordance with the national laws of Tanzania, Kenya, and Mozambique.

${ }^{3} \mathrm{~A}$ preliminary assessment was accomplished in 2008, revised in 2011 and updated in 2015. 
and the third attribute corresponds to "foundation measures".

\section{EIA Systems}

\subsection{Legal Provisions}

All five countries reviewed here have legal provisions concerning EIA. In Kenya, EIA legal requirements first appeared in the Environmental Management and Coordination Act (EMCA) of 1999 [8] and subsequently in the Environmental (Impact Assessment and Audit) Regulations of 2002 [9].

The first "formal" EIA process in Tanzania was undertaken for the Stiegeler's Gorge Power and Flood Control project in 1980. Since then, EIA practice has evolved comparatively slowly [10]. During a 1995 meeting of African environment ministries and government representatives in Durban to discuss EIA, the Tanzanian delegation signed the communiqué pledging affirmative action to promote EIA as a planning tool. This suggested a growing commitment to the process. However, a lack of resources, expertise and institutional capacity continue to present formidable barriers to implementation of this pledge [10]. In 2002, the National Environmental Management Council (NEMC) adopted several guidelines concerning EIA. National EIA policy and legislation was adopted with the promulgation of the Environmental Management Act in 2004 [11] and Environmental (Registration of Environmental Experts) Regulations, 2005 [12].

In Mozambique, EIA legal requirements first appeared in Decree 76/98 of 29 December 1998 [13]. Subsequent EIA experience led to its replacement with Decree 45/2004 of 29 September 2004 [14]. The Decree 42/2008, of 4 November [15], has introduced changes to the Decree 45/2004.

Prior to promulgation of EIA regulations in September 1997 (R1182, R1183, and R1184 of the Environment Conservation Act 73 of 1989), EIA was voluntary in South Africa. No procedures, methods, triggers, or products were codified in law, and no formal administrative systems were in place to process EIAs at any level of government, despite enabling clauses in the Environment Conservation Act [16]. During this period, voluntary EIAs were conducted according to the Integrated Environmental Management (IEM) procedure published by the Council for the Environment in 1989 and a set of six IEM guideline documents published by the National Department of Environmental Affairs and Tourism [17].

In post-Apartheid South Africa, environmental provisions were enshrined in the Bill of Rights, and EIA was given new impetus in the Environmental Management Policy published in 1997. EIA regulations were promulgated under the National Environmental Management Act No. 107 of 1998 (Republic of South Africa, 1998) [18], locating the administrative function at the provincial or second-tier government level [16]. Subsequent experience revealed problems with the regulations, including lack of clarity leading to inconsistent application of laws across provinces, as well as a process that was not as streamlined or flexible as it could be, lack of proper guidance and abuse of the public participation processes, and problems with the contents, quality and independence of EIA re- 
ports [19]. A new set of EIA regulations was drawn up and promulgated on 21 April 2006.

Angolan environmental legislation was updated in the early 1990s with the establishment of the State Secretariat for the Environment and subsequent adoption of the Environment Framework Act, Decree no. 5/98 of 19 June 1998 [13]. Article 16 of the Act requires mandatory EIAs for all undertakings that may have an impact on the balance and well-being of the environment and society. As provided for under Article 16(2), the government established more specific rules on EIA under the Decree on Environmental Impact Assessment (Decree no. 51/04) of 23 July 2004 [20]. In addition, the Decree on Environmental Licensing (Decree no. 59/07) [21] of 14 October 2007 provides additional guidance on the conduct of EIAs. Recently several guidelines on the terms of reference for the elaboration of EIA were published by the Ministry of Environment.

EIA was introduced into European Community law by the Directive (85/ 337/EEC) [2], which was adopted in July 1985 and amended in March 1997 (97/11/EC) [3]. The purpose of the EU EIA Directive is to insure that the consequences of environmentally sensitive projects are properly considered before they are carried out or authorized. EU Member States are required to comply with the EU EIA Directive.

\subsection{EIA Procedural Framework}

The EIA process comprises six main elements: screening, scoping, report preparation, public consultation, review, and decision making. The criteria and requirements for each element will vary between jurisdictions, as will the timeline for each element.

Screening determines whether or not a project proposal requires an EIA and what level of EIA is required. All the systems reviewed here use a fairly comprehensive list of projects to identify whether an EIA is required.

An important step in EIA systems, scoping identifies key issues (and non-issues) and concerns and evaluates, organizes, and presents them to assist in analysis and decision-making. Some form of scoping exists in the EIA systems of Kenya, Tanzania, Mozambique, and South Africa. However, there is no formal requirement for scoping in the EU Directive or in Angolan law.

All the EIA systems studied here require public participation, an EIA review stage, and mitigation and monitoring of impacts. All five of the African systems include a legal requirement for preparation of an Environmental Management Plan (EMP).

In all the countries examined here, the EIA is initiated by the proponent. In Kenya, Tanzania, Mozambique, and Angola the proponent is responsible for conducting an EIA. In South Africa, a pre-qualified Environmental Assessment Practitioner appointed by the proponent conducts an EIA.

\subsection{Institutional Framework}

Figures 1-5 set out the EIA institutional framework in the five African coun- 

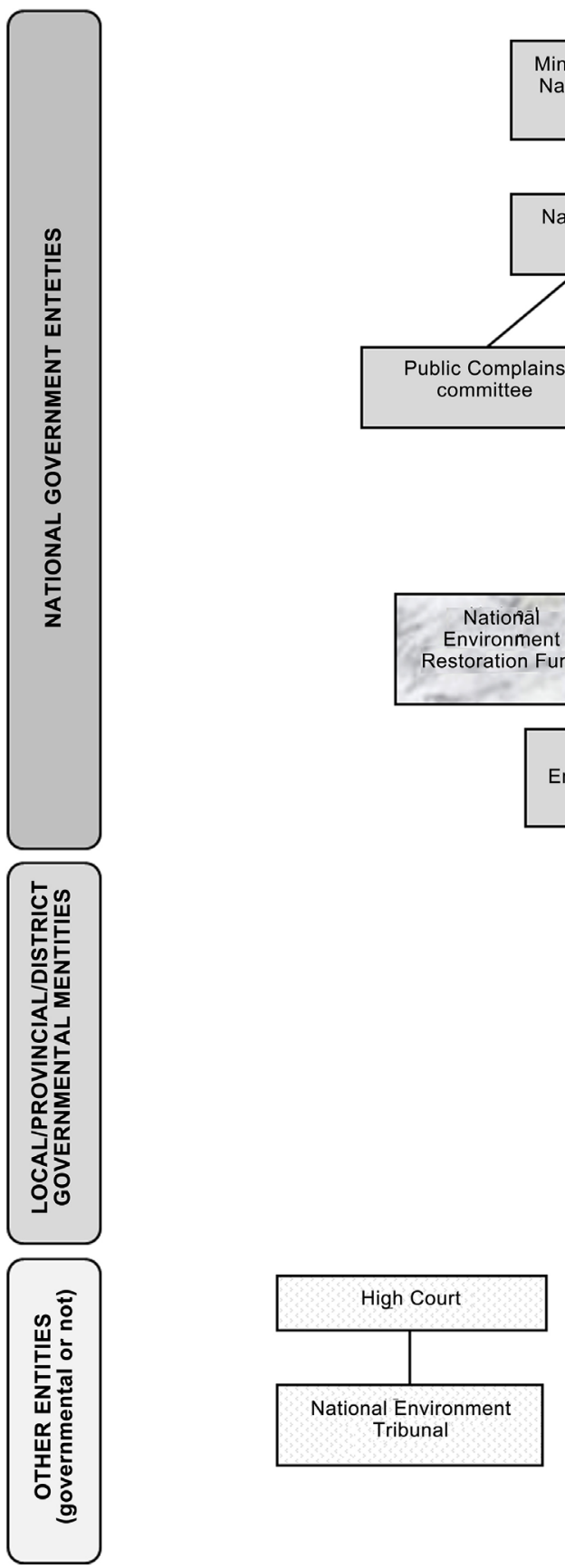
NGOS, interested and affected parties, others
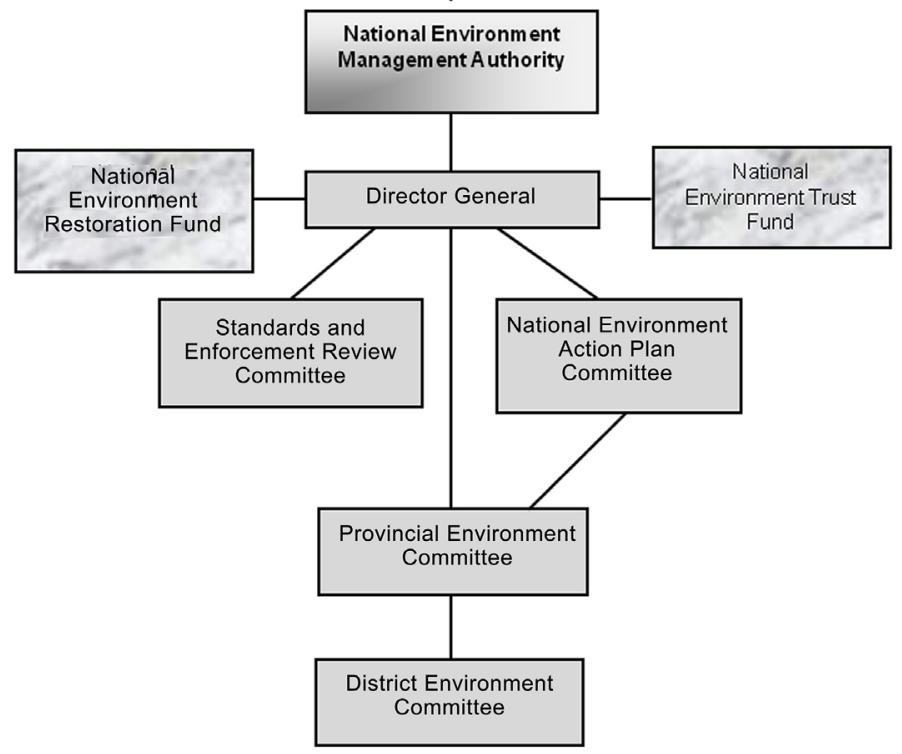

cial Environment

blic Complain committee

Ministry of environment

Wildlife

ational Environment Council

Legend:

Competent EIA Authority

Entities with responsibilities at the level of Environmental Policy/ Environmental Management/ Environmental Impact Assessment/ Strategic Environmental Assessment

Funds for research on environmental management, capacity-building, scholarships, etc.

Resolves Environmental Disputes

Research on policies

Figure 1. Institutional framework of the EIA process in Kenya. Description: This figure shows all Kenyan institutions (governmental or not) involved in the EIA decision-making process, as well as the road map for procedural arrangements. 


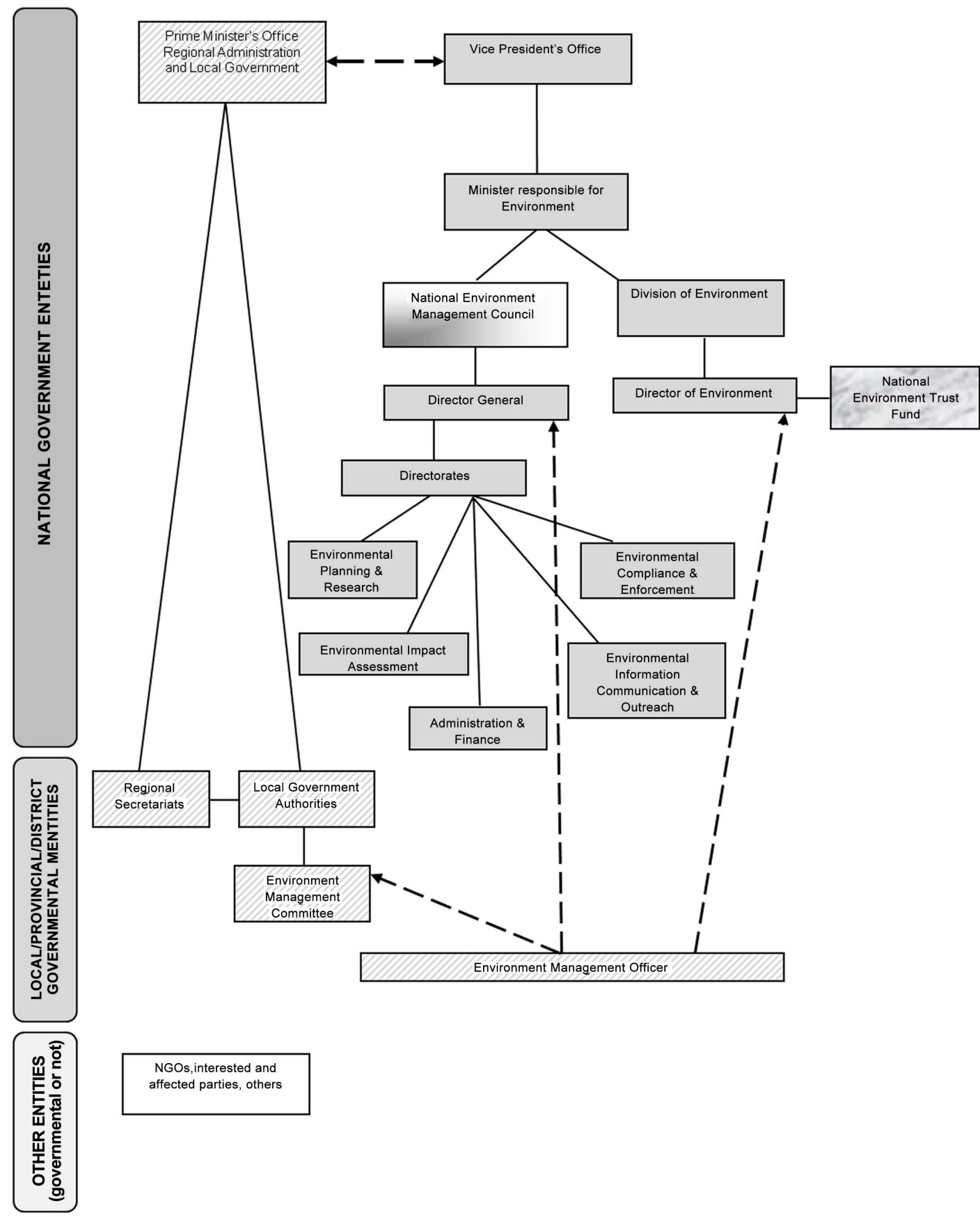

\section{Legend:}

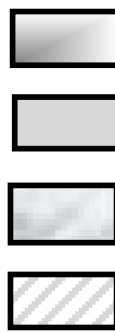

Competent EIA Authority

Entities with responsibilities at the level of Environmental Policy/ Environmental Management/ Environmental Impact Assessment/ Strategic Environmental Assessment

Funds for research on environmental management, capacity-building, scholarships, etc.

Local Government, Coordination and Support for Local Government Authorities

Figure 2. Institutional framework of the EIA process in Tanzania. Description: This figure shows all Tanzanian institutions (governmental or not) involved in the EIA decision-making process, as well as the road map for procedural arrangements. 


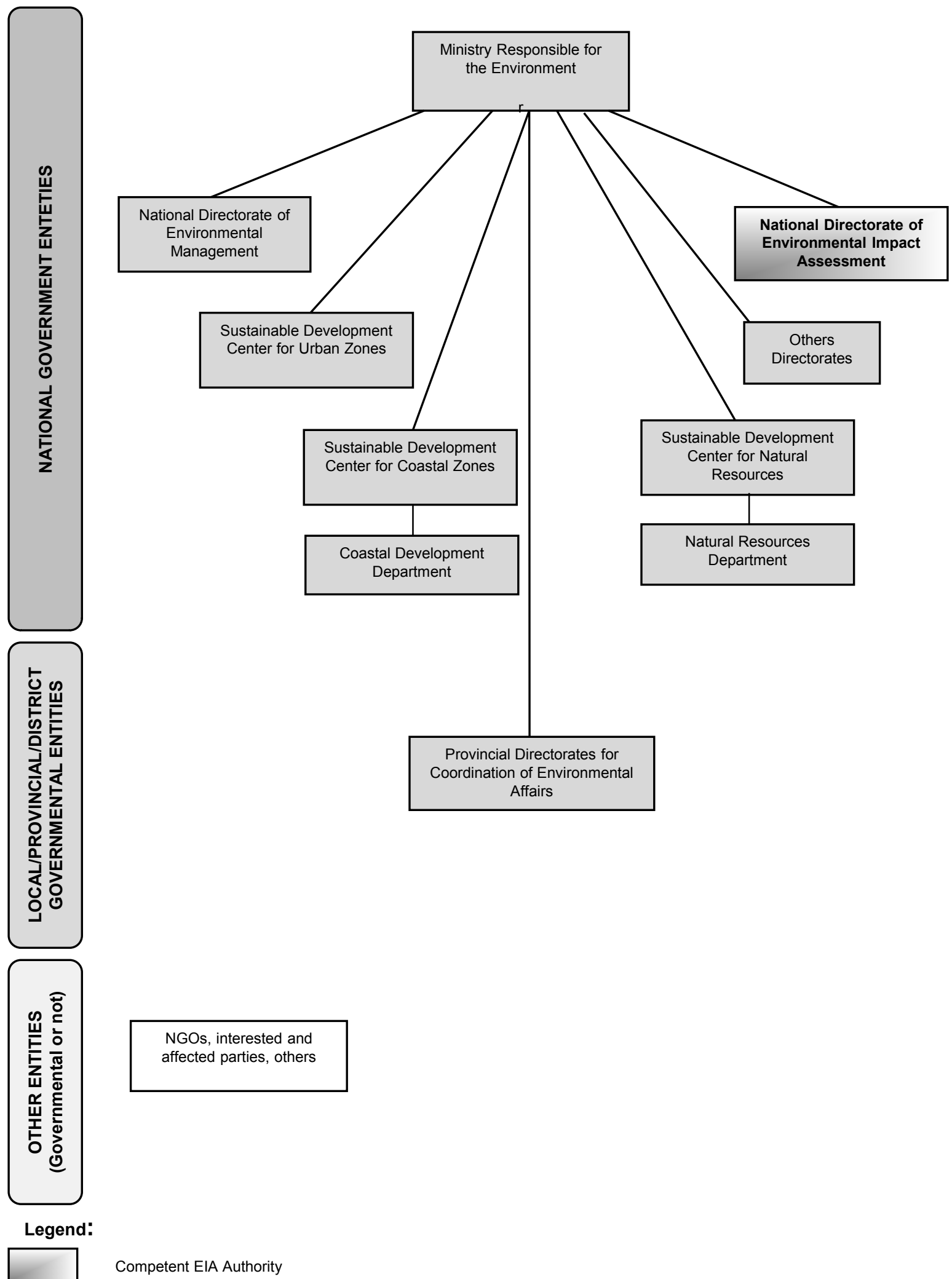

Entities with responsibilities at the level of Environmental Policy/ Environmental Management/ Environmental Impact Assessment/ Strategic Environmental Assessment

Figure 3. Institutional framework of the EIA process in Mozambique. Description: This figure shows all Mozambican institutions (governmental or not) involved in the EIA decision-making process, as well as the road map for procedural arrangements. 

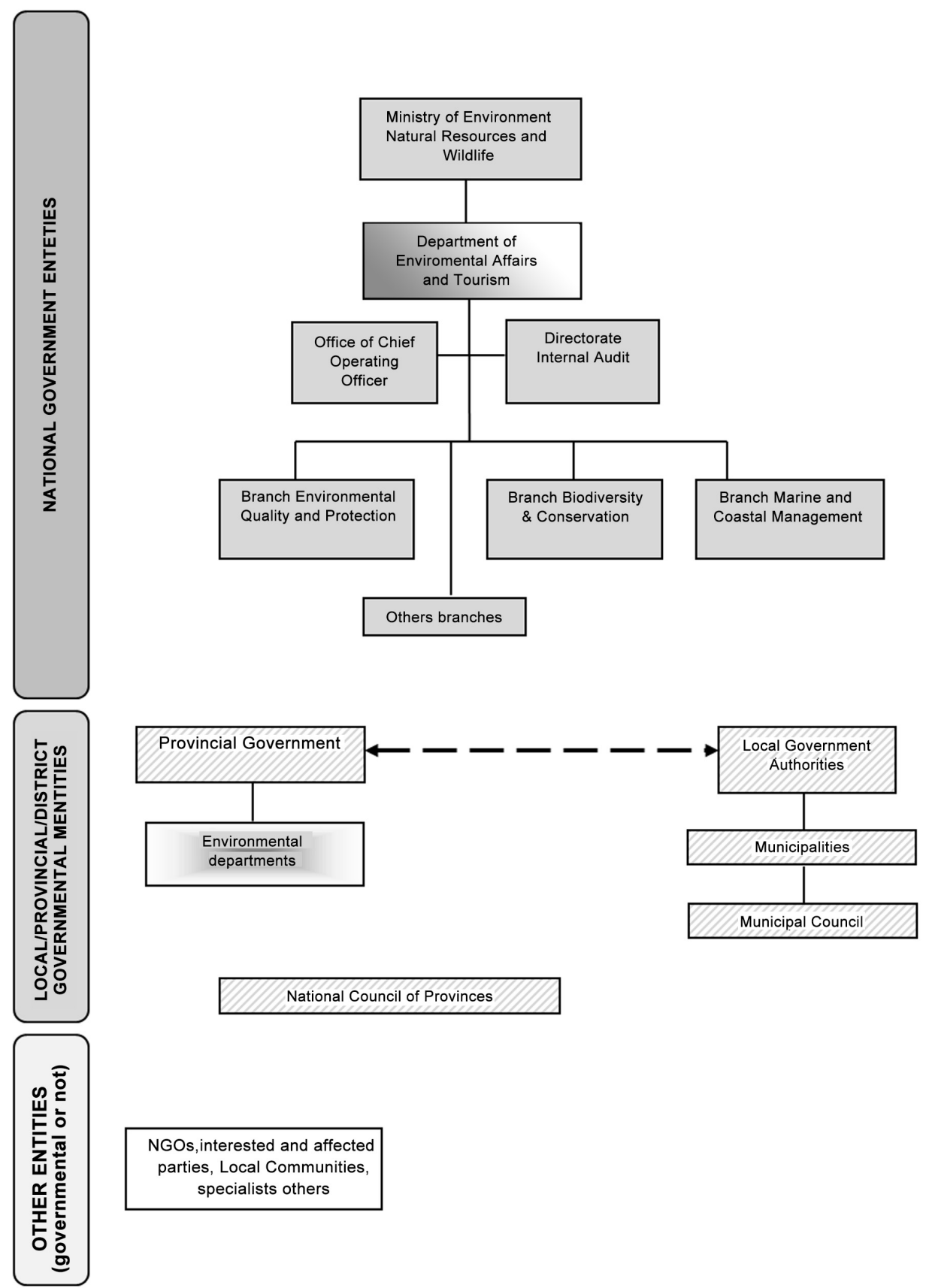

National Council of Provinces

\section{Legend:}

$$
\begin{gathered}
\text { NGOs, interested and affected } \\
\text { parties, Local Communities, } \\
\text { specialists others }
\end{gathered}
$$

Competent EIA Authority for projects of national importance

Competent EIA Authority for the other projects.

Entities with responsibilities at the level of Environmental Policy/ Environmental Management/ Environmental Impact Assessment/ Strategic Environmental Assessment

\section{Local Government and Provincial Government}

Figure 4. Institutional framework of the EIA process in South Africa. Description: This figure shows all South African institutions (governmental or not) involved in the EIA decision-making process, as well as the road map for procedural arrangements. 


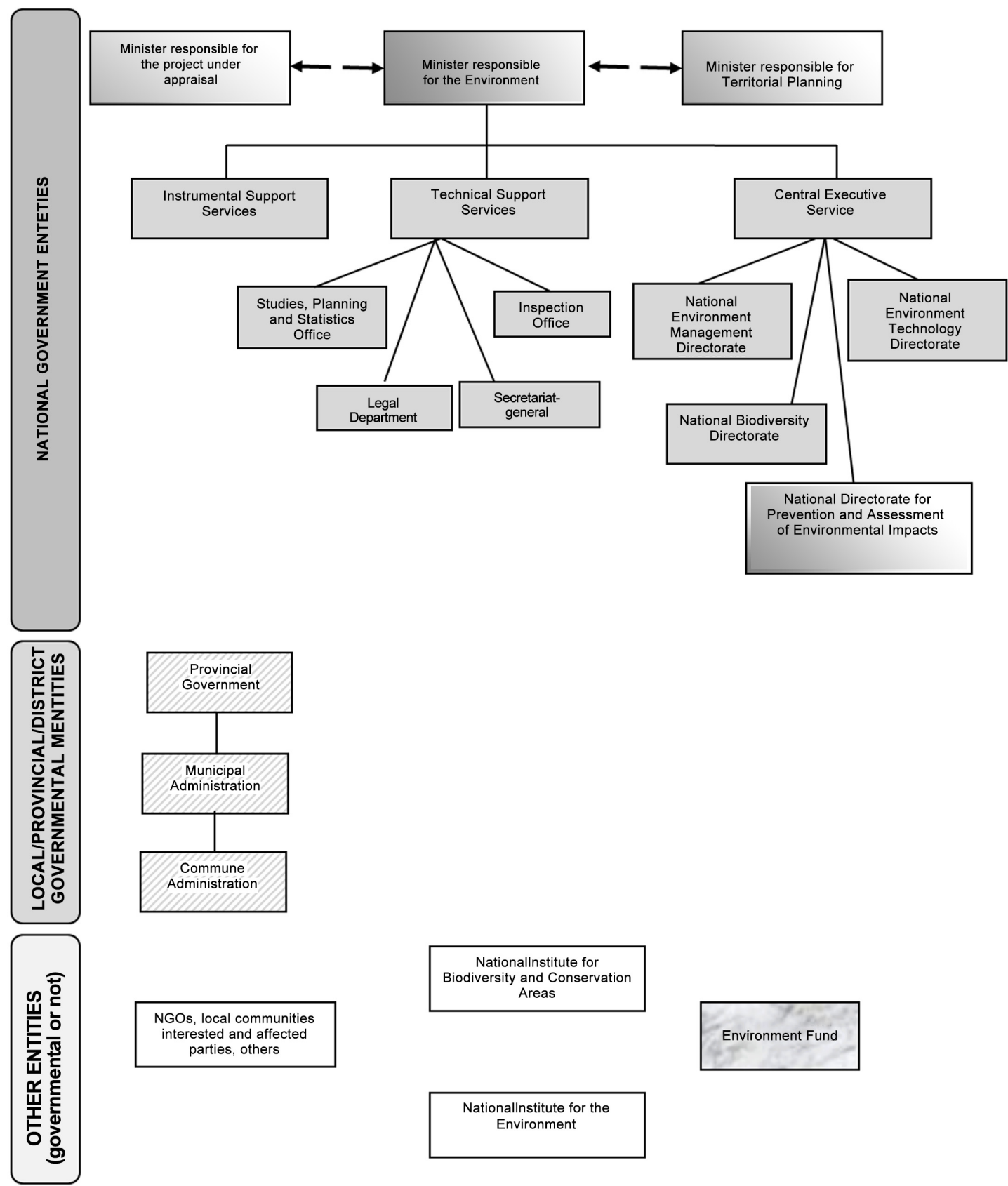

\section{Legend:}

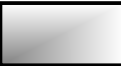

Competent EIA Authority/other Ministers where this competence is exercise jointly

Entities with responsibilities at the level of Environmental Policy/ Environmental Management/ Environmental Impact Assessment/ Strategic Environmental Assessment

Provincial Government and Municipal Administration

Finance technical scientific and environmental activities.

Figure 5. Institutional framework of the EIA process in Angola. Description: This figure shows all Angolan institutions (governmental or not) involved in the EIA decision-making process, as well as the road map for procedural arrangements. 
tries. In the EU, the institutional framework will vary from Member State to Member State. In general, the three levels of institutions participate in the EIA process: national government departments and entities, provincial or local government entities, and other governmental and non-state entities (e.g., local communities, research institutes, or non-governmental organizations). The institutional framework will pre-determine the leverage points for EIA inputs in the planning and decision-making processes, the focus of the EIA, the margin for consultation, facilitate participation by the general public and stakeholders, and provide the road map for procedural arrangements. Thus it is vital that the leading institution has a clear mandate and that the institutional framework is well defined. It is readily apparent from the literature review and field experience which institutions are involved in the EIA procedure, however, the process of interaction between them are not always clear in the African countries.

\section{Performance of EIA Systems}

\subsection{Systemic Measurement of Performance}

Table 1 summarises the overall comparison and evaluation of the six EIA systems against the systemic standards. The key features of each system are highlighted.

\subsubsection{EIA Legislation and Administration}

As noted above, the five African countries and the EU have each established a legal regime for EIA. EIA legislation in all of these jurisdictions applies to new projects and expansion and renovation of existing projects. Among the five African jurisdictions, only Mozambique prohibits the proponent from appealing a ruling.

These EIA systems also include legal or procedural specifications for deadlines (see Table 2). The deadlines apply at various points in the EIA process, i.e., preassessment, scoping review, terms of reference, and the final assessment itself.

Specific provisions are made for Strategic Environmental Assessments (SEAs). However, Angola doesn't include formal provisions for SEAs in their national legislation. In South Africa, SEAs have been implemented on a voluntary basis since the mid-1990s on the basis of specific guidelines for SEAs.

The regulations and procedures of the respective jurisdictions define the administrative arrangements and roles of the competent authorities involved in the EIA process. Each jurisdiction has identified a specific competent authority for overseeing the EIA process. Informal methods of coordination between competent authorities responsible for managing the EIA process and other entities responsible for pollution control or planning exist in Kenya, Mozambique, Tanzania, South Africa, and Angola. In the EU, coordination mechanisms vary from country to country.

\subsubsection{EIA Process}

\section{Screening}


Table 1. Performance of the EIA systems measured by systemic evaluation criteria. Description: This table summarises the overall comparison and evaluation of the six EIA systems using the systemic evaluation criteria. The most distinctive features of each system are highlighted.

\begin{tabular}{|c|c|c|c|c|c|c|}
\hline \multirow[b]{2}{*}{$\begin{array}{l}\text { Is the EIA } \\
\text { System based on } \\
\text { specific and clear } \\
\text { legal provisions? }\end{array}$} & Yes. In: & Yes. In: & & Yes. In: & & \\
\hline & $\begin{array}{l}\text { - Environmental } \\
\text { Management and } \\
\text { Coordination Act, } \\
1999 \\
\text { - Environmental } \\
\text { (Impact Assessment } \\
\text { and Audit) } \\
\text { Regulations, } 2003\end{array}$ & $\begin{array}{l}\text { - The Environmental } \\
\text { Management Act, 2004; } \\
\text { - The } \\
\text { Environmental } \\
\text { (Registration of } \\
\text { Environmental } \\
\text { Experts) regulations, } \\
\text { 2005. }\end{array}$ & $\begin{array}{l}\text { Yes. In Decree } \\
176 / 98 \text {, of December } \\
; ; 29, \text { revoked by } \\
\text { Decree } 45 / 2004 \text {, of } \\
\text { September } 29 \text {. } \\
\text { Decree } 42 / 2008 \text {, of } 4 \\
\text { November, change } \\
\text { the Decree } 45 / 2004 \text {. }\end{array}$ & $\begin{array}{l}\text { Promulgation of } \\
\text { EIA Regulations in } \\
\text { September } 1997 \\
\text { (R1182, R1183 and } \\
\text { R1184 on the } \\
\text { Environment } \\
\text { Conservation Act } 73 \\
\text { of 1989). } \\
\text { These Regulations } \\
\text { were revoked by the } \\
\text { EIA Regulations of } \\
21 \text { April } 2006 .\end{array}$ & $\begin{array}{l}\text { Yes. In Decree no. } \\
51 / 2004 \text {, of July } 23 .\end{array}$ & $\begin{array}{l}\text { Yes. Directive } \\
97 / 11 / E C \text { that } \\
\text { alters Directive } \\
85 / 337 / E E C \text {, on } \\
\text { evaluation of the } \\
\text { effects of specific } \\
\text { public and private } \\
\text { projects on the } \\
\text { environment. }\end{array}$ \\
\hline $\begin{array}{l}\text { Are there } \\
\text { mechanisms via } \\
\text { which the } \\
\text { promoter or } \\
\text { members of the } \\
\text { general public } \\
\text { may file appeals } \\
\text { against the } \\
\text { decision taken? }\end{array}$ & $\begin{array}{l}\text { When a project is no } \\
\text { included in the list } \\
\text { that specifies the } \\
\text { projects which are } \\
\text { obligatorily subject } \\
\text { to an EIA, and the } \\
\text { project may affect } \\
\text { the environment, the } \\
\text { NEMA (National } \\
\text { Environmental } \\
\text { Management } \\
\text { Authority) will } \\
\text { determine whether } \\
\text { or not it is necessary } \\
\text { to carry out an EIA. } \\
\text { If the promoter does } \\
\text { not agree with } \\
\text { NEMA's decision } \\
\text { concerning the } \\
\text { obligation to carry } \\
\text { out an EIA it may } \\
\text { appeal against the } \\
\text { decision in Court } \\
\text { within a maximum } \\
\text { of } 14 \text { days. } \\
\text { Any person who } \\
\text { disagrees with, or } \\
\text { whose interests are } \\
\text { damaged as a result } \\
\text { of NEMA's decision, } \\
\text { approving or } \\
\text { rejecting the EIA, } \\
\text { may present an } \\
\text { appeal in Court } \\
\text { within } 60 \text { days (after } \\
\text { the date of the } \\
\text { decision). }\end{array}$ & $\begin{array}{l}\text { Any person who } \\
\text { disagrees with, or } \\
\text { whose interests are } \\
\text { harmed as a result of } \\
\text { the Minister's decision, } \\
\text { approving or rejecting } \\
\text { the EIA, may appeal } \\
\text { against the decision in } \\
\text { the Environmental } \\
\text { Appeal Court. }\end{array}$ & None. & $\begin{array}{l}\text { If the notice of the } \\
\text { appeal is addressed } \\
\text { to the Minister, the } \\
\text { appeal should be } \\
\text { submitted to the } \\
\text { DEAT (Department } \\
\text { of Environmental } \\
\text { Affairs and } \\
\text { Tourism). If it is } \\
\text { addressed to the } \\
\text { MEC, the appeal } \\
\text { should be submitted } \\
\text { to the Provincial } \\
\text { Department } \\
\text { responsible for } \\
\text { environmental } \\
\text { affairs. If it is } \\
\text { addressed to the } \\
\text { delegated body of } \\
\text { the State, the appeal } \\
\text { should be presented } \\
\text { to the respective } \\
\text { body. }\end{array}$ & $\begin{array}{l}\text { An appeal against the } \\
\text { decision of the Minis- } \\
\text { ter responsible for the } \\
\text { Environment may be } \\
\text { made under the } \\
\text { general terms of } \\
\text { administrative } \\
\text { litigation and } \\
\text { procedures. }\end{array}$ & $\begin{array}{l}\text { Specific legal } \\
\text { provisions for each } \\
\text { Member State. }\end{array}$ \\
\hline
\end{tabular}




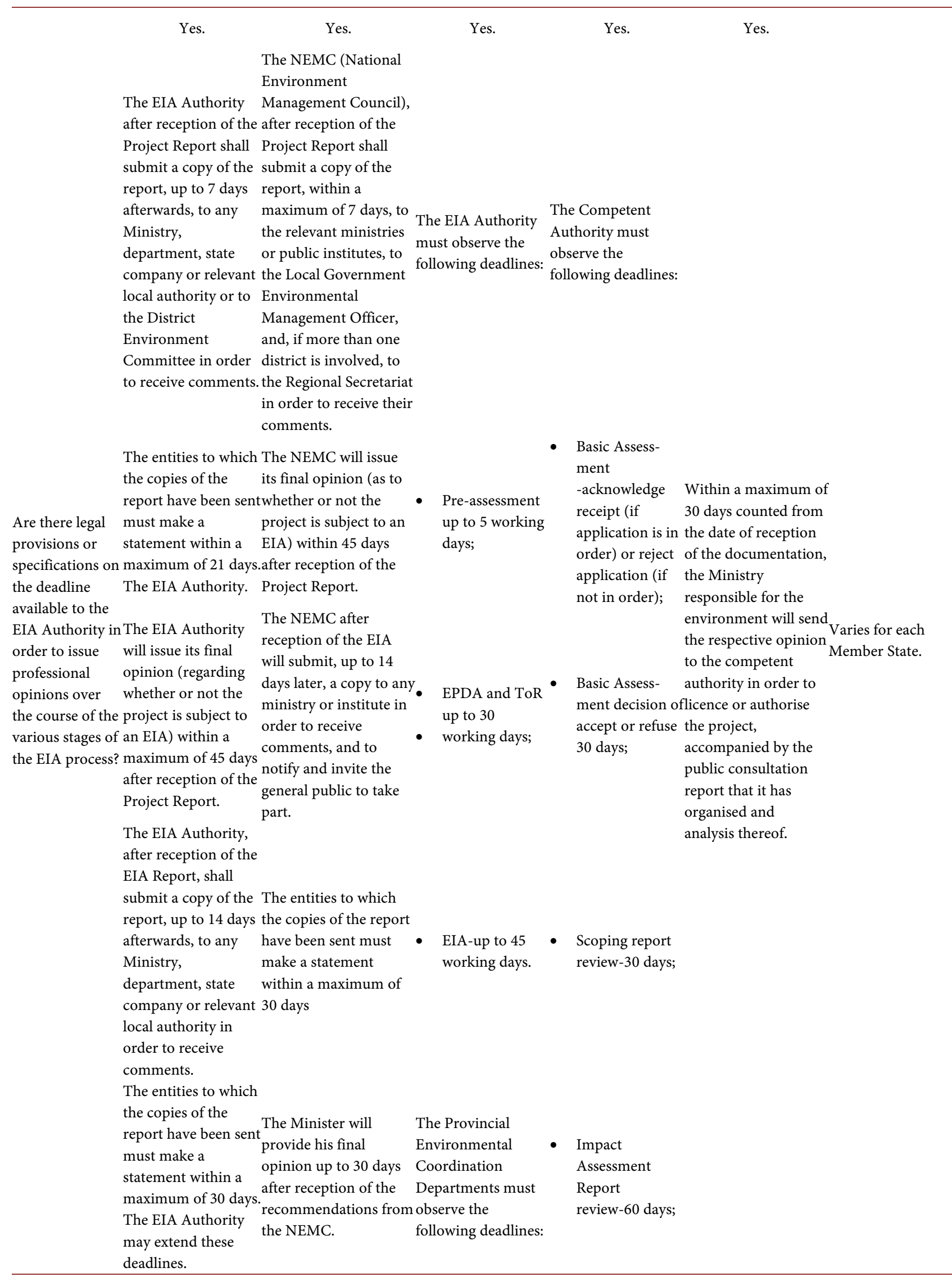




\section{Continued}

The EIA Authority

will issue its final

opinion concerning

the EIA up to 3

months after

reception of the EIA

Report.
- Pre-assessment -up to 8 working days;

- Terms of

- Reference-up to 15 working days;

- $\quad$ SES-up to 30 working days.

The deadlines are counted from the date of registration of the entry of

documentation to the competent authority, and are interrupted whenever complementary information is requested and resumed after such information has been duly resented by the proponent.

In exceptional circumstances, the Minister for

Coordination of

Environmental Affairs, on the basis of a duly well-grounded proposal presented by DNEIA or DPCA, may extend the established deadlines in accordance with the specific characteristics of each case.
- decision to grant or refuse Environmental Authorization 45 days;

- must in writing grant or refuse authorization in respect of all or part of the activity-10 days.
Are there provisions on public consultation deadlines?
The EIA Authority, up to 14 days after reception of the EIA Report, shall invite the general public to make oral or written comments in relation to the report.

Yes. Yes.

The Council shall within thirty days of receipt of an Environmental Impact Statement decide whether or not to convene a public hearing for purposes of The convocation for a public audience or consultation shall be made public at least 15 days prior to the meeting, using the appropriate means for collecting submissionthe respective publicaa comments on the tion. proposed project or undertaking.
Yes.

The public consultation shall be carried out during a period of at least five days and no more than 10 days. At the end of the period set for the public consultation, a succinct report will be drawn up,

Varies for each No. Member State. within the following 8 days, specifying the diligent proceedings taken, the participation recorded and the conclusions to be drawn. 


\section{Continued}

\begin{tabular}{|c|c|c|c|c|c|}
\hline & $\begin{array}{l}\text { Publication of a } \\
\text { notice concerning } \\
\text { the project, during } \\
\text { two consecutive } \\
\text { weeks in a national } \\
\text { circulation } \\
\text { newspaper. } \\
\text { Produce an } \\
\text { advertisement in the } \\
\text { official and local } \\
\text { language in a } \\
\text { national coverage } \\
\text { radio station at least } \\
\text { once per week during } \\
\text { two consecutive } \\
\text { weeks. } \\
\text { At least three public } \\
\text { meetings shall be } \\
\text { held. The notices } \\
\text { shall be sent out with } \\
\text { at least one week } \\
\text { prior notice before } \\
\text { the meetings. }\end{array}$ & $\begin{array}{l}\text { The date and venue of } \\
\text { the public hearing shall } \\
\text { be publicitized at least } \\
\text { one week prior to the } \\
\text { meeting. } \\
\text { On the conclusion of } \\
\text { the public hearing, the } \\
\text { presiding officer shall } \\
\text { comply a report of the } \\
\text { views presented at the } \\
\text { public hearing and } \\
\text { submit the report to the } \\
\text { gDirector General within } \\
\text { fourteen days from the } \\
\text { date of completion of } \\
\text { the public hearing. }\end{array}$ & $\begin{array}{l}\text { All oral or written } \\
\text { presentations or } \\
\text { manifestations } \\
\text { produced within the } \\
\text { framework of the } \\
\text { public participation } \\
\text { process, presented to } \\
\text { local bodies and/or } \\
\text { to the proponent, up } \\
\text { to } 10 \text { days before the } \\
\text { revision period of } \\
\text { the Simplified } \\
\text { Environmental } \\
\text { Study (SES) or of the } \\
\text { EIA will be } \\
\text { registered and will } \\
\text { be considered in the } \\
\text { decision of the } \\
\text { Technical } \\
\text { Evaluation } \\
\text { Committee, } \\
\text { provided that they } \\
\text { are related to the } \\
\text { environmental } \\
\text { impacts of the } \\
\text { activities. }\end{array}$ & & \\
\hline $\begin{array}{l}\text { Are there } \\
\text { provisions on } \\
\text { the deadlines for } \\
\text { presenting } \\
\text { appeals against a } \\
\text { decision? }\end{array}$ & $\begin{array}{l}14 \text { days-For the } \\
\text { promoter to } \\
\text { appeal against } \\
\text { NEMA's } \\
\text { decision } \\
\text { concerning the } \\
\text { obligation to } \\
\text { carry out an EIA; } \\
\text { 60 days (After } \\
\text { the date of the } \\
\text { decision)-for any } \\
\text { person who } \\
\text { disagrees or } \\
\text { whose interests } \\
\text { are affected by } \\
\text { the decision of } \\
\text { NEMA, as to } \\
\text { whether or not } \\
\text { approve an EIA, } \\
\text { may appeal in } \\
\text { the Court. }\end{array}$ & No. & 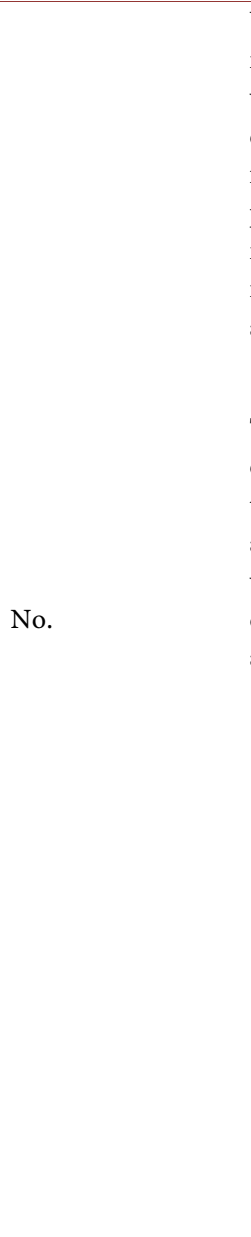 & $\begin{array}{l}\text { Yes. The appeal } \\
\text { must be presented } \\
\text { within a maximum } \\
\text { of } 30 \text { days counted } \\
\text { from the date of } \\
\text { presentation of the } \\
\text { notice of the } \\
\text { intention to file an } \\
\text { appeal. } \\
\text { The Minister, MEC } \\
\text { or delegated body of } \\
\text { the State, as } \\
\text { appropriate, may, in } \\
\text { writing, extend the } \\
\text { deadline for filing anNo. } \\
\text { appeal. }\end{array}$ & $\begin{array}{l}\text { Varies for each } \\
\text { Member State. }\end{array}$ \\
\hline
\end{tabular}




\section{Continued}

\begin{tabular}{|c|c|c|c|c|c|}
\hline $\begin{array}{l}\text { Are there } \\
\text { provisions on } \\
\text { Strategic } \\
\text { Environmental } \\
\text { Assessments } \\
\text { (SEA)? }\end{array}$ & $\begin{array}{l}\text { In accordance with } \\
\text { Article 42, paragraph } \\
1 \text {, of the } \\
\text { Environmental } \\
\text { (Impact Assessment } \\
\text { and Audit) } \\
\text { Regulations of 2003, In accordance with } \\
\text { the agencies, in Article 104, paragraph } \\
\text { conjunction with 1, of the 2004 } \\
\text { NEMA, shall submit Environmental } \\
\text { all proposals for Management Act, the } \\
\text { policies, programmesSEA of Regulations, } \\
\text { and plans for a SEA, Policies, Strategies, } \\
\text { in order to determineProgrammes and Plans } \\
\text { which are the most shall be drawn up. } \\
\text { ecologically and } \\
\text { economically } \\
\text { efficient when } \\
\text { applied individually } \\
\text { or in combination } \\
\text { with others. }\end{array}$ & Yes. & $\begin{array}{l}\text { No. In South Africa, } \\
\text { SEAs have been } \\
\text { widely implemented } \\
\text { on a voluntary basis } \\
\text { since the mid-1990s } \\
\text { (over } 50 \text { SEAs were } \\
\text { identified). There are } \\
\text { specific guidelines } \\
\text { for the SEA. }\end{array}$ & No. & $\begin{array}{l}\text { Yes, Directive } \\
\text { 2001/42/EC of } \\
\text { the European } \\
\text { Parliament } \\
\text { and Council, } \\
\text { of June 27, } \\
\text { 2001, on } \\
\text { evaluation of } \\
\text { the effects of } \\
\text { specific plans } \\
\text { and } \\
\text { programmes } \\
\text { on the } \\
\text { environment. }\end{array}$ \\
\hline
\end{tabular}

\section{Administration}

\begin{tabular}{|c|c|c|c|c|c|c|}
\hline $\begin{array}{l}\text { Which is the } \\
\text { competent EIA } \\
\text { authority? }\end{array}$ & $\begin{array}{l}\text { NEMA (National } \\
\text { Environment } \\
\text { Management } \\
\text { Authority) }\end{array}$ & $\begin{array}{l}\text { Minister Responsible } \\
\text { for the Environment } \\
\text { Issues-has the final } \\
\text { decision as to whether } \\
\text { an EIA will be } \\
\text { approved, conditionally } \\
\text { approved or rejected. }\end{array}$ & $\begin{array}{l}\text { Ministry for } \\
\text { Coordination of } \\
\text { Environmental } \\
\text { Affairs (MCEA), } \\
\text { through the } \\
\text { National } \\
\text { Environmental } \\
\text { Impact } \\
\text { Assessment } \\
\text { Department } \\
\text { (DNEIA) and the } \\
\text { Provincial } \\
\text { Environmental } \\
\text { Action } \\
\text { Coordination } \\
\text { Department } \\
\text { (DPCA). }\end{array}$ & $\begin{array}{l}\text { DEAT is responsible } \\
\text { for evaluating } \\
\text { projects of national } \\
\text { importance (i.e. } \\
\text { projects that cross } \\
\text { provincial or } \\
\text { national } \\
\text { boundaries). The } \\
\text { environmental } \\
\text { departments of the } \\
\text { various provincial } \\
\text { governments are } \\
\text { responsible for } \\
\text { evaluating } \\
\text { applications that } \\
\text { have been submitted } \\
\text { in terms of the EIA } \\
\text { regulations. }\end{array}$ & $\begin{array}{l}\text { In accordance with Decree } \\
\text { no. 51/04,of July 23, the } \\
\text { competency for the AIA } \\
\text { procedure pertains to the } \\
\text { Minister responsible for the } \\
\text { Environment, who will } \\
\text { designate the entity } \\
\text { responsible for drawing up } \\
\text { the procedure. Since } \\
\text { publication of Decree-Law } \\
\text { no. } 4 / 09 \text {, of May } 18 \text {, the } \\
\text { National Directorate for } \\
\text { Prevention and Assessment } \\
\text { of Environmental Impacts } \\
\text { is the service within the } \\
\text { Ministry of the } \\
\text { Environment responsible } \\
\text { for AIA procedures. Since } \\
\text { then, it has no longer be } \\
\text { necessary for the Minister } \\
\text { responsible for the } \\
\text { Environment to designate } \\
\text { the entity responsible for } \\
\text { drawing up this procedure. } \\
\text { This competency is } \\
\text { exercised jointly with the } \\
\text { Minister responsible for the } \\
\text { project under appraisal and } \\
\text { the Minister responsible for } \\
\text { Territorial Planning, in the } \\
\text { case of projects located } \\
\text { within urban perimeters or } \\
\text { which cut across } \\
\text { settlements. }\end{array}$ & $\begin{array}{l}\text { Each Member } \\
\text { State has at } \\
\text { least one } \\
\text { competent } \\
\text { authority for } \\
\text { EIAs. }\end{array}$ \\
\hline
\end{tabular}




\section{Continued}

\begin{tabular}{|c|c|c|c|c|c|c|}
\hline $\begin{array}{l}\text { Who is } \\
\text { responsible for } \\
\text { Revision of the } \\
\text { Environmental } \\
\text { Impact Study } \\
\text { (EIA)? }\end{array}$ & NEMA & $\begin{array}{l}\text { The NEMC (National } \\
\text { Environment } \\
\text { Management Council) } \\
\text { in collaboration with } \\
\text { inter-sectorial } \\
\text { consultative } \\
\text { committees }\end{array}$ & $\begin{array}{l}\text { Technical } \\
\text { Evaluation } \\
\text { Committee (TEC) }\end{array}$ & $\begin{array}{l}\text { DEAT or an ex- } \\
\text { pert in the area }\end{array}$ & $\begin{array}{l}\text { The Ministries } \\
\text { responsible for the } \\
\text { Environment or the } \\
\text { expert in the area. }\end{array}$ & $\begin{array}{l}\text { Each Member } \\
\text { State has a } \\
\text { Structure/ } \\
\text { commission } \\
\text { responsible for } \\
\text { revision of the } \\
\text { EIA. }\end{array}$ \\
\hline $\begin{array}{l}\text { What are the } \\
\text { sectorial } \\
\text { responsibilities } \\
\text { of the authoritie } \\
\text { in the EIA } \\
\text { process? }\end{array}$ & $\begin{array}{l}\text { NEMA can submit a } \\
\text { copy of the EIA } \\
\text { report to any } \\
\text { Ministry, } \\
\text { s department, state } \\
\text { company or relevant } \\
\text { local authority for } \\
\text { comment. }\end{array}$ & $\begin{array}{l}\text { Environmental Experts } \\
\text { Advisor Community }\end{array}$ & $\begin{array}{l}\text { Relevant sectorial } \\
\text { authorities will be } \\
\text { represented in the } \\
\text { TEC. }\end{array}$ & $\begin{array}{l}\text { Relevant sectorial } \\
\text { authorities are } \\
\text { consulted. }\end{array}$ & $\begin{array}{l}\text { Any relevant } \\
\text { Ministry, department, } \\
\text { state company or local } \\
\text { authority is consulted. }\end{array}$ & $\begin{array}{l}\text { A different } \\
\text { situation in each } \\
\text { Member State. }\end{array}$ \\
\hline
\end{tabular}

What is the level

of coordination Any Ministry,

with any other department, state Environmental Experts TEC

pollution controlcompany or relevant Advisor Community

TEC

and planning local authority.

Any relevant

sectorial

authorities
Any relevant

Ministry, department, A different state company or local situation in each authority. organisation?

\section{EIA Process}

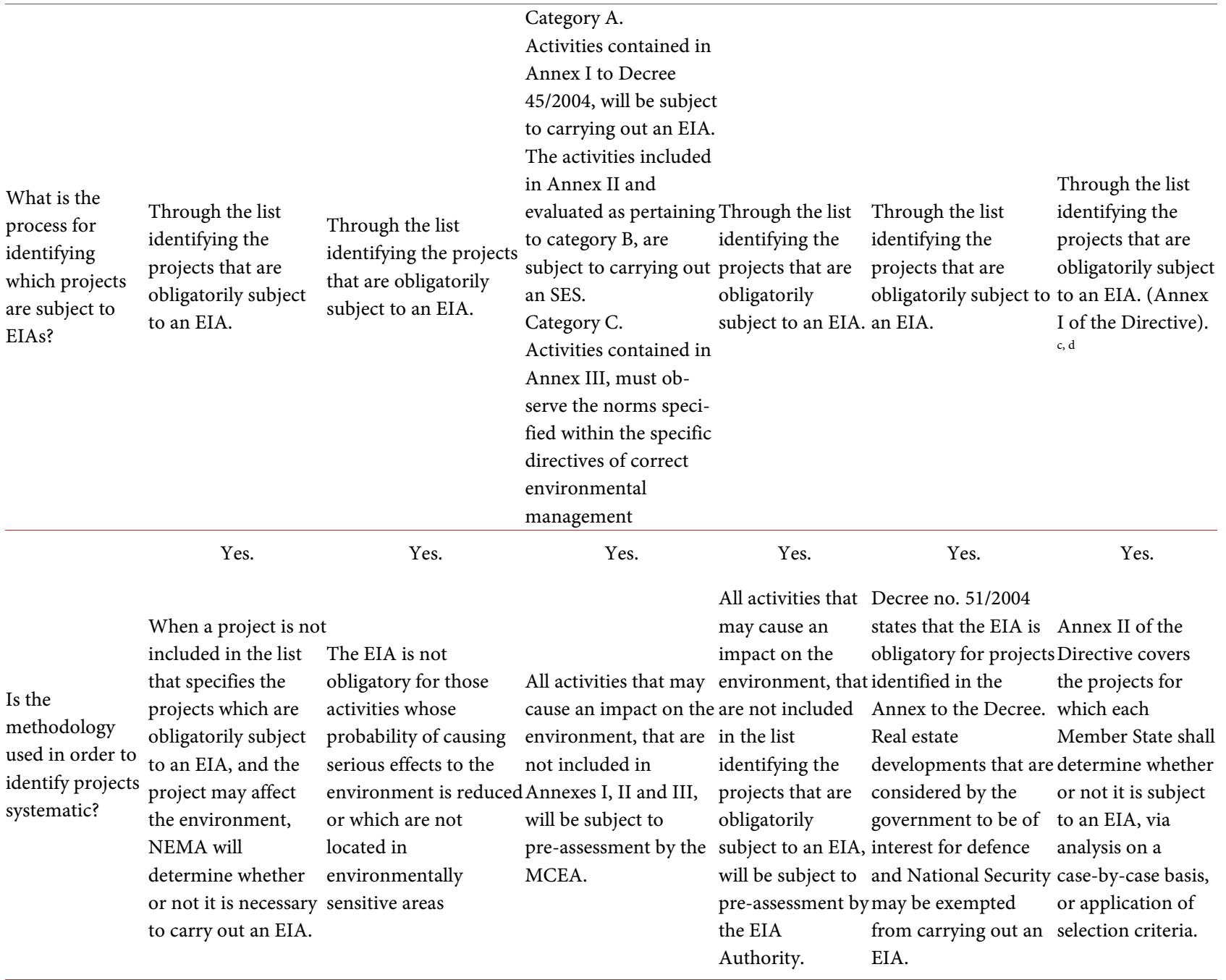




\section{Continued}

\begin{tabular}{|c|c|c|c|c|c|c|}
\hline & & $\begin{array}{l}\text { For the list of activities } \\
\text { identified in Annex II } \\
\text { of the Screening and } \\
\text { Scoping Guidelines, the } \\
\text { NEMC will evaluate } \\
\text { whether or not an EIA } \\
\text { is necessary. }\end{array}$ & & & & $\begin{array}{l}\text { Annex III specifies } \\
\text { these criteria, } \\
\text { indicating the } \\
\text { probability of } \\
\text { negative effects on } \\
\text { the environment. }\end{array}$ \\
\hline $\begin{array}{l}\text { Are there legal } \\
\text { requirements for } \\
\text { carrying out } \\
\text { scoping (Scoping } \\
\text { Definition Pro- } \\
\text { posals)? If so, } \\
\text { what are the } \\
\text { respective de- } \\
\text { tails? }\end{array}$ & $\begin{array}{l}\text { Yes. } \\
\text { Drawing up the } \\
\text { gcoping and Terms } \\
\text { of Reference (ToR) } \\
\text { for all projects } \\
\text { subject to an EIA } \\
\text { (by the propo- } \\
\text { nent). }\end{array}$ & $\begin{array}{l}\text { Yes. } \\
\text { Preparation of the } \\
\text { scoping and Terms of } \\
\text { Reference (ToR) for } \\
\text { projects included in the } \\
\text { obligatory list (by the } \\
\text { proponent). }\end{array}$ & $\begin{array}{l}\quad \text { Yes. } \\
\text { Study of } \\
\text { Environmental } \\
\text { Pre-viability and } \\
\text { definition of Scope } \\
\text { e(EPDA) is obligatory } \\
\text { for all activities } \\
\text { classified as pertain- } \\
\text { ing to category A. }\end{array}$ & $\begin{array}{l}\text { A Scoping shall be } \\
\text { drawn up for all } \\
\text { activities subject to } \\
\text { an EIA. }\end{array}$ & No. & $\begin{array}{l}\text { There are no re- } \\
\text { quirements in the } \\
\text { legal Directives for } \\
\text { drawing up a } \\
\text { Scoping Definition } \\
\text { Proposal. }{ }^{\text {e }}\end{array}$ \\
\hline $\begin{array}{l}\text { Are there public } \\
\text { consultations } \\
\text { during the } \\
\text { scoping process? }\end{array}$ & No. & $\begin{array}{l}\text { Yes. } \\
\text { The proponent/ } \\
\text { certified and registered } \\
\text { experts or a registered } \\
\text { company shall draw up } \\
\text { a list of interested or } \\
\text { affected parties and will } \\
\text { consult them. Minutes } \\
\text { should be drawn up } \\
\text { following these } \\
\text { consultations referring } \\
\text { to the topics addressed } \\
\text { and which questions/ } \\
\text { constraints were raised. } \\
\text { These minutes should } \\
\text { be duly signed by all } \\
\text { intervening parties. }\end{array}$ & 11 & $\begin{array}{l}\text { The pre-qualified } \\
\text { expert shall carry out } \\
\text { a public } \\
\text { consultation. }\end{array}$ & Not applicable & No. ${ }^{f, g}$ \\
\hline $\begin{array}{l}\text { Does the scoping } \\
\text { need to be } \\
\text { revised? If so, } \\
\text { who is } \\
\text { responsible for } \\
\text { the revision. }\end{array}$ & g & No. & $\begin{array}{l}\quad \text { Yes. } \\
\text { The Technical } \\
\text { Evaluation } \\
\text { Committee } \\
\text { (inter-sectorial } \\
\text { committee } \\
\text { responsible for } \\
\text { analysing the } \\
\text { technical documents } \\
\text { drawn up within the } \\
\text { framework of the } \\
\text { EIA) shall carry out } \\
\text { the revision. }\end{array}$ & $\begin{array}{l}\text { The scoping needs to } \\
\text { be revised. } \\
\text { Revision may be } \\
\text { carried out by the } \\
\text { Competent } \\
\text { Authority. }\end{array}$ & o & $\begin{array}{l}\text { Specific legal } \\
\text { provisions for each } \\
\text { Member State. }\end{array}$ \\
\hline $\begin{array}{l}\text { Are there } \\
\text { requirements } \\
\text { which oblige the } \\
\text { promoter to } \\
\text { demonstrate that } \\
\text { alternatives to } \\
\text { the project were } \\
\text { taken into } \\
\text { consideration? }\end{array}$ & $\begin{array}{l}\text { Yes. } \\
\text { Analysis of the } \\
\text { alternatives must } \\
\text { include } \\
\text { identification of } \\
\text { alternative } \\
\text { locations, design } \\
\text { and technology. }\end{array}$ & $\begin{array}{l}\text { Analysis of the } \\
\text { alternatives must } \\
\text { include identification } \\
\text { of alternative locations, } \\
\text { design and } \\
\text { technology. }\end{array}$ & \begin{tabular}{l}
\multicolumn{1}{c}{ Yes. } \\
Viable alternatives \\
shall be identified for \\
the planning, \\
construction and \\
operation stages and, \\
in the case of \\
temporary activities, \\
for their respective \\
deactivation.
\end{tabular} & \begin{tabular}{l}
\multicolumn{1}{c}{ Yes. } \\
Analysis of the \\
alternatives must \\
include identification \\
of alternative \\
locations, type of \\
activity to be \\
developed, design, \\
technology and \\
operational aspects \\
of the activity
\end{tabular} & $\begin{array}{l}\text { Yes. } \\
\text { Analysis of the } \\
\text { alternatives must } \\
\text { ninclude identification } \\
\text { of all the technological } \\
\text { alternatives and } \\
\text { alternative locations, } \\
\text { confronting them with } \\
\text { the possibility that the } \\
\text { project will not be } \\
\text { executed. }\end{array}$ & $\begin{array}{l}\quad \text { Yes. } \\
\text { The alternatives } \\
\text { studied by the } \\
\text { proponent must be } \\
\text { described, } \\
\text { indicating the } \\
\text { reasons for the } \\
\text { final choice (taking } \\
\text { into consideration } \\
\text { the effects on the } \\
\text { environment). }{ }^{\mathrm{h}, \mathrm{i}}\end{array}$ \\
\hline
\end{tabular}




\section{Continued}

Choice of the
location, design and

technology proposed

in the project should

be duly

well-grounded.

Are the details of The contents of the the EIA Report EIA Report are dedefined in the scribed in detail in legislation? the EIA legislation.

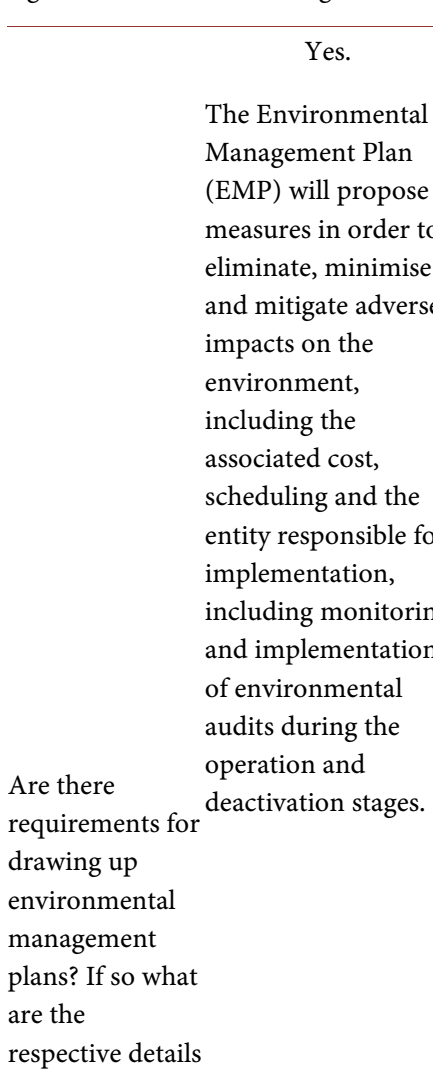

Due grounds should be provided, justifying the choice of the location proposed in the project together with the proposed process and technology .

The contents of the EIAThe contents of the The contents of the Report are described in EIA Report are EIA Report are detail in the EIA legislation and in the Guide described in detail indescribed in detail in the EIA legislation the EIA legislation and in the Guide and in the Guide

$\begin{array}{lll}\text { Yes. Yes. } & \text { Yes. }\end{array}$
Yes. The contents of the EIA Report are The contents of the described in detail in described in detail EIA Report are
The Environmental

Management Plan

(EMP) will propose measures in order to eliminate, minimise and mitigate adverse impacts on the environment, including educational
the associated cost, programme scheduling and the entity responsible for implementation
The Environmental

Management Plan of the activity will

include monitoring The Environmental impacts, an Management Plan environmental (EMP) will contain information on: accident contingency plans.
According to Decree

no. $51 / 2004$, a

supervision and monitoring

- the person responsible for drawing up the plan and evidence of his technical capacities for this task; programme of the Specific legal positive and negative provisions for each impacts must be Member State. drawn up, indicating the factors and parameters to be taken into consideration.

- measures

designed to

manage or

mitigate the

environmental

impacts foreseen

in the planning

and design,

pre-constructio

n, construction,

operation stages,

rehabilitation of

the environment

and

de-activation

(when suitable); 


\section{Continued}

- aspects of the

activity covered

by the EMP

( detailed

description);

- The person who

will be

responsible for

implementing

the measures;

- Scheduling of

implementation

of the measures

specified within

the EMP, when

appropriate;

- Proposal of a

mechanism to

monitor

compliance with

the terms

established in

the EMP and the

respective

reports.

Yes.

Yes.

Yes.

Yes.

Yes.

Yes.

The mitigation

measures shall

include the means

and forms of

management, use all

the best available

technologies and

good practices

existing in

Recommendations or a engineering

Are there structures in order to

requirements for proposing measures to minimise the negative aspects

minimise environmental impacts? If so,

are such

measures

presented for

each of the

project stages? plan aimed at mitigating the likely

impacts should be presented. project

(environmental, socioeconomic and cultural), and also foster the positive aspects.
A set of measures shall be proposed aimed at minimisin or avoiding negative effects and fostering positive effects of the activity on the biophysical and socioeconomic environment.
A set of measures shall be proposed and aimed at minimising or avoiding the negative effects and fostering the positive effects of an activity.
Measures designed to mitigate the negative Varies for each impacts will be defined.
Member State. 1, m
Although legislation does not specify that these measures must

Although legislation Although legislation does not specify that does not specify that these measures mus be presented for each presented for each of of the project's the project's development stages, development stages, this practice exists. this practice exists.

\section{be presented for} each of the project's development stages, this practice exists. be presented for each

that these measures of the project's must be presented development for each of the stages, some of the project's Environmental development stages. Impact Studies to

practice exists. 


\section{Continued}

\begin{tabular}{|c|c|c|c|c|c|c|}
\hline $\begin{array}{l}\text { Are there re- } \\
\text { quirements for } \\
\text { drawing up a } \\
\text { monitoring } \\
\text { plan? If so, what } \\
\text { should be } \\
\text { included within } \\
\text { this plan. }\end{array}$ & $\begin{array}{l}\text { Monitoring during } \\
\text { the operation and } \\
\text { deactivation stages } \\
\text { are included in the } \\
\text { EMP. } \\
\text { The elements that } \\
\text { should be } \\
\text { contemplated are not } \\
\text { established. }\end{array}$ & $\begin{array}{l}\text { There is no } \\
\text { specification of the terms } \\
\text { t that should be } \\
\text { contemplated. }\end{array}$ & $\begin{array}{l}\text { The Environmental } \\
\text { Management Plan of } \\
\text { the activity includes } \\
\text { monitoring of the } \\
\text { impacts. } \\
\text { There is no specifica- } \\
\text { tion of the terms that } \\
\text { should be contem- } \\
\text { plated. }\end{array}$ & $\begin{array}{l}\text { Contemplated } \\
\text { within the scope of } \\
\text { the EMP. } \\
\text { - There is no } \\
\text { tspecification of the } \\
\text { terms that should } \\
\text { be contemplated. }\end{array}$ & $\begin{array}{l}\text { According to Decree } \\
\text { no. } 51 / 2004 \text {, a } \\
\text { f supervision and } \\
\text { monitoring } \\
\text { programme of the } \\
\text { positive and negative } \\
\text { impacts must be } \\
\text { drawn up, indicating } \\
\text { the factors and } \\
\text { parameters to be } \\
\text { taken into } \\
\text { consideration. }\end{array}$ & $\begin{array}{l}\text { Varies for each } \\
\text { Member State. }\end{array}$ \\
\hline $\begin{array}{l}\text { Are there re- } \\
\text { quirements for } \\
\text { revision of the } \\
\text { EIA Report? If } \\
\text { so, how does this } \\
\text { take place? }\end{array}$ & $\begin{array}{l}\text { The Ministry, de- } \\
\text { partments, state } \\
\text { companies or local } \\
\text { authorities with } \\
\text { management and } \\
\text { control functions of } \\
\text { the environment and } \\
\text { natural resources } \\
\text { s may revise the EIA } \\
\text { report in order to } \\
\text { guarantee that it } \\
\text { complies with the } \\
\text { developed reference } \\
\text { terms. }\end{array}$ & $\begin{array}{l}\text { - Balance between the } \\
\text { short and long-term } \\
\text { socioeconomic } \\
\text { benefits as } \\
\text { contrasted to the } \\
\text { damages caused to } \\
\text { the physical and } \\
\text { human environment; } \\
\text { - } \\
\text { The nature of the } \\
\text { project and } \\
\text { whether or not it } \\
\text { complies with } \\
\text { borne by the proponent. } \\
\text { the project under } \\
\text { analysis. The respective } \\
\text { durironmental } \\
\text { process, make a visit in } \\
\text { order to inspect or verify } \\
\text { quality standards; } \\
\text { possible mitigation } \\
\text { measures or other } \\
\text { corrective measures; } \\
\text { Comments retrieved } \\
\text { during the public } \\
\text { consultations and } \\
\text { other consultation } \\
\text { processes; } \\
\text { amongst others. } \\
\text { - }\end{array}$ & $\begin{array}{l}\text { The MCEA will } \\
\text { designate the } \\
\text { Technical } \\
\text { Evaluation } \\
\text { Committee (TEC) } \\
\text { and revise the EPDA } \\
\text { and the EIA report. } \\
\text { The TEC will draw } \\
\text { up the technical } \\
\text { report of the } \\
\text { revision and } \\
\text { respective } \\
\text { well-grounded } \\
\text { technical opinion, } \\
\text { and will issue a final } \\
\text { assessment } \\
\text { statement. This } \\
\text {; statement will be } \\
\text { sent to the EIA } \\
\text { Authority for the } \\
\text { final decision. }\end{array}$ & $\begin{array}{l}\text { Yes. Revision is } \\
\text { carried out by the } \\
\text { EIA Authority } \\
\text { (DEAT) or by an } \\
\text { expert in the } \\
\text { respective area. }\end{array}$ & $\begin{array}{l}\text { According to } \\
\text { prevailing legislation, } \\
\text { EIA reviews are } \\
\text { carried out by } \\
\text { technicians from the } \\
\text { Ministry of the } \\
\text { Environment/ } \\
\text { National Directorate } \\
\text { for Prevention and } \\
\text { Assessment of } \\
\text { Environmental } \\
\text { Impacts. Nonethe- } \\
\text { less, no EIA review } \\
\text { criteria have been } \\
\text { established. }\end{array}$ & $\begin{array}{l}\text { Specific legal } \\
\text { provisions for each } \\
\text { Member State. } n\end{array}$ \\
\hline
\end{tabular}




\section{Continued}

Which body or bodies are responsible for revision of the EIA Report?
The Ministry, departments, state companies or local authority with management and control functions of the environment or natural resources, in collaboration with NEMA.
The NEMC may create

inter-sectorial

consultative

committees, at the

national level and,

when suitable, at the MCEA and TEC.

level of the Local

Government Authority

in order to provide

advice during revision

of the EIA report.

The committees must be constituted by at least 12 specialists, in order to guarantee multidisciplinarity

The TEC is

constituted by

(always an uneven number of members):

The inter-sectorial consultative committees may, subject to approval from NEMC's

Director-General, incorporate other persons necessary for their correct

functioning.

The minimum quorum necessary for holding a meeting of the committee is $2 / 3$.

On the basis of the NEMC's

recommendations, the Minister will issue his decision.
- a representative of the DNEIA, who will chair the Committee; In practice, EIA reviews have been carried out by technicians from the Ministry of the the Ministry DEAT or an Environment/ Varies for each responsible for the expert in the area. National Directorate Member State. $\mathrm{n}$ area of the proposed activity; for Prevention and

Assessment of Environmental Impacts and/or experts in the field.

- a representative of the local authority for the area where the activity is located, if the proposed location for implementation of the activity has been authorised in this territory;

- Other

representatives of environmental government bodies, teaching institutions or research centres; 
- A specialised

technician in the

area of the

respective

activity

requested or

contracted by

the EIA

Authority,

whenever this

proves to be

necessary.

\begin{tabular}{|c|c|c|c|c|c|c|}
\hline $\begin{array}{l}\text { May the } \\
\text { proponent take } \\
\text { part in the } \\
\text { revision process } \\
\text { or respond to } \\
\text { questions raised } \\
\text { during revision } \\
\text { of the EIA } \\
\text { Report? }\end{array}$ & $\begin{array}{l}\text { The proponent may } \\
\text { respond to questions } \\
\text { raised during } \\
\text { revision of the EIA } \\
\text { Report. }\end{array}$ & $\begin{array}{l}\text { The proponent may } \\
\text { respond to questions } \\
\text { raised during revision } \\
\text { of the EIA Report. } \\
\text { The practice exists, in } \\
\text { several projects, of the } \\
\text { proponent and certified } \\
\text { and registered expert(s) } \\
\text { (or registered } \\
\text { company) to attend the } \\
\text { inter-sectorial } \\
\text { consultative } \\
\text { committees. }\end{array}$ & $\begin{array}{l}\text { Additional } \\
\text { information and } \\
\text { amendments may be } \\
\text { requested. }\end{array}$ & $\begin{array}{l}\text { The proponent } \\
\text { may respond } \\
\text { to questions } \\
\text { eraised during } \\
\text { revision of the } \\
\text { EIA Report. }\end{array}$ & Not applicable. & $\begin{array}{l}\text { Varies for each } \\
\text { Member State. } \\
\mathrm{n}\end{array}$ \\
\hline $\begin{array}{l}\text { Is the EIA Re- } \\
\text { port made } \\
\text { available for a } \\
\text { Public } \\
\text { Consultation? If } \\
\text { so, how does this } \\
\text { take place. }\end{array}$ & $\begin{array}{l}\text { The proponent } \\
\text { should be given the } \\
\text { opportunity to make } \\
\text { a presentation and } \\
\text { respond to the } \\
\text { questions raised } \\
\text { during the Public } \\
\text { Consultation. }\end{array}$ & $\begin{array}{l}\text { rAny constraints raised } \\
\text { during the consultation } \\
\text { of interested parties } \\
\text { during the scoping } \\
\text { stage, shall be duly } \\
\text { addressed when } \\
\text { drawing up the EIA. } \\
\text { Whenever part of the } \\
\text { general public expresses } \\
\text { ea strong concern in } \\
\text { relation to the project } \\
\text { rand its impact is likely } \\
\text { to be extensive and } \\
\text { significant, the NEMC } \\
\text { will organise a Public } \\
\text { Consultation. }\end{array}$ & $\begin{array}{l}\text { Yes. } \\
\text { The Terms of } \\
\text { Reference (ToR) } \\
\text { governing the } \\
\text { process of drawing } \\
\text { up the EIA or SES } \\
\text { must describe the } \\
\text { Public Consultation } \\
\text { procedure to be } \\
\text { followed. } \\
\text { The proponent is } \\
\text { sresponsible for } \\
\text { public participation, } \\
\text { during the } \\
\text { conception stage of } \\
\text { the activity, up to } \\
\text { submission of the } \\
\text { EIA and SES } \\
\text { reports. }\end{array}$ & $\begin{array}{l}\text { Yes. } \\
\text { Chapter } 6 \text { of } \\
\text { the EIA } \\
\text { Regulations of } \\
\text { April 21, 2006 } \\
\text { presents details } \\
\text { of the Public } \\
\text { Consultation } \\
\text { process. }\end{array}$ & $\begin{array}{l}\text { No. } \\
\text { The public consolidation } \\
\text { process begins with prior } \\
\text { disclosure of a non-technical } \\
\text { summary of the Environmental } \\
\text { Impact Study, specifying the } \\
\text { s key effects that the project may } \\
\text { generate in the environment, in } \\
\text { particular use of natural re- } \\
\text { sources, emission of polluting } \\
\text { agents, creation of disturbances } \\
\text { (ranging from intensity of } \\
\text { lighting/heat to noise and } \\
\text { smells) or elimination of } \\
\text { residues, identifying the } \\
\text { preventive methods used in } \\
\text { order to evaluate and diminish } \\
\text { the effects on the environment, } \\
\text { together with the project's } \\
\text { impact on the socioeconomic } \\
\text { environment. Disclosure of } \\
\text { these elements must respect } \\
\text { industrial confidentiality and } \\
\text { observe legal norms protecting } \\
\text { non-patented technical know- } \\
\text { ledge. In the framework of the } \\
\text { public consultation, } \\
\text { statements and complaints that } \\
\text { have been presented, related to } \\
\text { the project, will be considered } \\
\text { and appraised. }\end{array}$ & $\begin{array}{l}\text { Yes. } \\
\text { The } \\
\text { methodology } \\
\text { used in order } \\
\text { to carry out } \\
\text { Public } \\
\text { Consultations } \\
\text { varies in each } \\
\text { Member State. }\end{array}$ \\
\hline
\end{tabular}




\section{Continued}

The Presiding Officer will draw up a report The Public including the Consultation must be viewpoints presented held in a convenient during the Public Consultation and present it to the Director General.
Public participation

is obligatory for

category A activities,

and is optional for

category B. However

it should always take

place whenever the

activities imply:

permanent or

temporary

displacement of

populations or

communities;

displacement of

goods or restriction

on the use of natural

resources.

An opportunity must

be given to the

proponent to make a

presentation and

The public

participation process

should result in a

respond to questions

raised during the Public

Final Report.

Consultation

The person chairing the

Public Consultation, in

collaboration with the

NEMC, will determine

the procedural rules of

the Public

Consultation.

This person will also be

responsible for drawing

up a report including

the viewpoints

presented during the

Public Consultation

and then present it to

the Director General.
Is the EIA

Report altered in

function of the No legal provisions

comments exist for this

received during purpose.

the Public

Consultation?
Feedback from the consultations made shall be incorporated in the EIA.
No legal provisions exist for this purpose.
The NEMC may create

Is there a systematic acceptability on the decision-making basis of the process?
NEMA will decide upon the project's environmental

\section{inter-sectorial}

consultative

committees, at the

national level and,

when suitable at the

considerations take

from the revision

process. level of the Local

level of the Local will revise the EPDA
Government Authority, ${ }_{\text {or }}$ or revise the SES. in order to provide advice during revision of the EIA report.

n

The Technical

Evaluation

Committee (TEC)

will revise the EPDA 


\begin{tabular}{|c|c|c|c|c|c|}
\hline & & $\begin{array}{l}\text { The Minister will issue } \\
\text { his decision on the } \\
\text { basis of the NEMC's } \\
\text { recommendations }\end{array}$ & $\begin{array}{l}\text { The TEC will draw } \\
\text { up the duly } \\
\text { well-grounded } \\
\text { technical revision } \\
\text { report and the } \\
\text { respective technical } \\
\text { opinion and will } \\
\text { issue a final } \\
\text { assessment } \\
\text { statement. } \\
\text { In the case of an } \\
\text { EIA, this declaration } \\
\text { will be sent to the } \\
\text { EIA Authority for } \\
\text { the final decision. } \\
\text { In the case of an } \\
\text { SES, the PDCA will } \\
\text { take a decision on } \\
\text { the environmental } \\
\text { viability of the pro- } \\
\text { posed activity. }\end{array}$ & & \\
\hline $\begin{array}{l}\text { Is there } \\
\text { experience in } \\
\text { Strategic } \\
\text { Environmental } \\
\text { Assessment? }\end{array}$ & Yes. Limited. & Yes. Limited. & 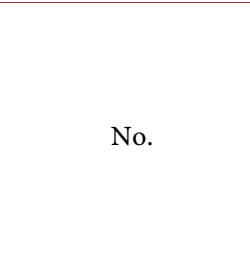 & $\begin{array}{l}\text { In South Africa, } \\
\text { SEAs have been } \\
\text { widely implemented } \\
\text { on a voluntary basis No. } \\
\text { since the mid-1990s } \\
\text { (over } 50 \text { SEAs were } \\
\text { identified). }\end{array}$ & $\begin{array}{l}\text { Various SEAs } \\
\text { implemented in } \\
\text { each Member } \\
\text { State. }\end{array}$ \\
\hline
\end{tabular}

All systems reviewed here use fairly comprehensive lists of projects in order to identify whether an EIA is required.

As specified in the First Schedule of the Tanzanian EIA regulations, screening procedures are based on two lists of projects: those requiring a mandatory EIA, and small-scale activities and enterprises that required registration (but may or may not require EIA). The Second Schedule lists the screening criteria to be used.

The screening procedures in Mozambique relate to three lists of activities (Categories A, B and C). All Category A activities identified in Appendix I must draw up an Environmental Impact Report (EIR). The activities included in Appendix II, and those classified as category B, are subject to a Simplified Environmental Impact Report (SER). Activities that might have an environmental impact and are not listed in Appendices I and III are subject to pre-assessment by the Ministry for Environmental Coordination (MCEA).

In South Africa, the Environmental Assessment Practitioner (EAP) manages the Application for an Environmental Authorisation on behalf of the proponent and determines which process to follow: Basic Assessment, Scoping and EIA, or request an Exemption. In general, activities identified in Listing Note 1 no. R386 are subject to a Basic Assessment and those in Listing Note 2 no. R387 are subject to Scoping and an EIA. If the competent authority cannot reach a decision based on a Basic Assessment, it can order the proponent to subject the activity to 
Table 2. Performance of the EIA system measured by foundation evaluation criteria. Description: This table summarises the performance of the six EIA systems using the relevant foundation criteria. The most distinctive features of each system are highlighted.

\begin{tabular}{|c|c|c|c|c|c|c|}
\hline $\begin{array}{l}\text { EVALUATION } \\
\text { CRITERIA }\end{array}$ & KENYA & Tanzania & MOZAMBIQUE & $\begin{array}{l}\text { SOUTH } \\
\text { AFRICA }\end{array}$ & Angola & $\begin{array}{c}\text { European Union } \\
\text { (EU) }\end{array}$ \\
\hline & Yes. & Yes. & Yes. & Yes. & No. & Yes. \\
\hline $\begin{array}{l}\text { Are there General } \\
\text { and/or Specific } \\
\text { Guides, including } \\
\text { any sectorial } \\
\text { procedures, drawn } \\
\text { up by the } \\
\text { competent } \\
\text { authority? }\end{array}$ & $\begin{array}{l}\text { General Guidelines } \\
\text { on Environmental } \\
\text { Impact } \\
\text { Assessments and } \\
\text { Administrative } \\
\text { Procedures. }\end{array}$ & $\begin{array}{l}\text { Guidelines for: } \\
\text { General guidelines } \\
\text { on Environmental } \\
\text { Impact Assessment } \\
\text { and Procedures; } \\
\text { Screening and } \\
\text { Proposal of } \\
\text { Definition of the } \\
\text { Framework; } \\
\text { Requirements and } \\
\text { content of the } \\
\text { Report; Revision } \\
\text { and Monitoring. } \\
\text { There is also a } \\
\text { checklist with } \\
\text { environmental } \\
\text { characteristics. }\end{array}$ & $\begin{array}{l}\text { General Guidelines } \\
\text { on Environmental } \\
\text { Impact } \\
\text { Assessments and } \\
\text { Public } \\
\text { Participation. }\end{array}$ & $\begin{array}{l}\text { Guidelines for: } \\
\text { drawing up } \\
\text { Environmental } \\
\text { Impact Reports; } \\
\text { Criteria for } \\
\text { determining } \\
\text { alternatives in } \\
\text { EIA; drawing up } \\
\text { Environmental } \\
\text { Management } \\
\text { Plans; for } \\
\text { determine } \\
\text { cumulative } \\
\text { effects; drawing } \\
\text { up Revisions of } \\
\text { the EIA. }\end{array}$ & & $\begin{array}{l}\text { Guidelines for } \\
\text { drawing up Revision } \\
\text { of EIAs, Screening } \\
\text { and the Proposal of } \\
\text { the Definition of the } \\
\text { Framework. There } \\
\text { are also checklists for } \\
\text { Screening processes } \\
\text { and the Proposal of } \\
\text { the Definition of the } \\
\text { Framework. }\end{array}$ \\
\hline $\begin{array}{l}\text { Does the EIA } \\
\text { System need to be } \\
\text { monitored, and if } \\
\text { so, is it altered in } \\
\text { function of } \\
\text { feedback from } \\
\text { previous } \\
\text { experience? }\end{array}$ & $\begin{array}{l}\text { Monitoring of the } \\
\text { EIA System is } \\
\text { required in } \\
\text { national legislation. } \\
\text { There is virtually } \\
\text { no monitoring of } \\
\text { the EIA system. }\end{array}$ & $\begin{array}{l}\text { Monitoring of the } \\
\text { EIA System is } \\
\text { required in } \\
\text { national legislation. } \\
\text { There is virtually } \\
\text { no monitoring of } \\
\text { the EIA system }\end{array}$ & $\begin{array}{l}\text { Monitoring of the } \\
\text { EIA System is } \\
\text { required in } \\
\text { national legislation. } \\
\text { There is virtually } \\
\text { no monitoring of } \\
\text { the EIA system }\end{array}$ & $\begin{array}{l}\text { Monitoring of } \\
\text { the EIA System } \\
\text { is not required } \\
\text { in national } \\
\text { legislation. } \\
\text { Nonetheless, } \\
\text { such monitoring } \\
\text { does exist }{ }^{\text {a }} \\
\text { Feedback from } \\
\text { previous } \\
\text { experience } \\
\text { (around } 9 \text { years) } \\
\text { was taken into } \\
\text { consideration } \\
\text { when drawing } \\
\text { up the new EIA } \\
\text { regulations }\end{array}$ & $\begin{array}{l}\text { There is virtually no } \\
\text { monitoring of the EIA } \\
\text { system. }\end{array}$ & $\begin{array}{l}\text { Monitoring of the } \\
\text { EIA System is } \\
\text { required by the } \\
\text { Directive. } \\
\text { Monitoring of the } \\
\text { EIA System is } \\
\text { implemented and, if } \\
\text { necessary, is altered } \\
\text { in order to } \\
\text { contemplate } \\
\text { feedback from past } \\
\text { experience. }\end{array}$ \\
\hline $\begin{array}{l}\text { What is the source } \\
\text { of skills for } \\
\text { coordinating EIA? }\end{array}$ & $\begin{array}{l}\text { Skills for } \\
\text { coordinating EIAs } \\
\text { exists in } \\
\text { Universities, } \\
\text { Research Institutes } \\
\text { and private } \\
\text { consultancy firms. }\end{array}$ & $\begin{array}{l}\text { Skills for } \\
\text { coordinating EIAs } \\
\text { exists in } \\
\text { Universities, } \\
\text { Research Institutes } \\
\text { and private } \\
\text { consultancy firms. }\end{array}$ & $\begin{array}{l}\text { Skills for } \\
\text { coordinating EIAs } \\
\text { exists in } \\
\text { Universities, } \\
\text { Research Institutes } \\
\text { and private } \\
\text { consultancy firms. }\end{array}$ & $\begin{array}{l}\text { Skills for } \\
\text { coordinating } \\
\text { EIAs exists in } \\
\text { Universities, } \\
\text { Research } \\
\text { Institutes and } \\
\text { private } \\
\text { consultancy } \\
\text { firms. }\end{array}$ & $\begin{array}{l}\text { Skills for coordinating } \\
\text { EIAs exists in } \\
\text { Universities, Research } \\
\text { Institutes and private } \\
\text { consultancy firms. }\end{array}$ & $\begin{array}{l}\text { Skills for } \\
\text { coordinating EIAs } \\
\text { exists in Universities, } \\
\text { Research Institutes } \\
\text { and private } \\
\text { consultancy firms. }\end{array}$ \\
\hline
\end{tabular}

Scoping and EIA. A proponent can also obtain written authorisation from the competent authority to subject an activity listed in Listing Note $1 \mathrm{n}$. ${ }^{\circ}$ R386 to Scoping and EIA.

In Angola, the EIA is obligatory for projects identified in the Annex to Decree no. 51/04. Real estate developments considered by the government to be of in- 
terest for defence and national security may be exempted from an EIA.

The screening procedure in the EU EIA Directive is based on two lists of activities: Annex 1 projects requiring a mandatory EIA, and Annex 2 projects for which Member States must determine whether or not an EIA is required on a case-by-case basis or by applying criteria thresholds. Annex 3 stipulates environmental effects criteria to be applied to projects for Annex 2 screening decisions.

\section{Scoping}

Some form of scoping exists in the EIA systems of Kenya, Tanzania, Mozambique and South Africa. In Angola there is no formal requirement for scoping. There is also no formal requirement for scoping in the EU Directive. However, a number of Member States (e.g., Germany) have made provisions for scoping in their national legislation. Other Member States (e.g., Ireland) either have certain non-mandatory arrangements for scoping or have encouraged developers to use this practice.

In Kenya, for those projects on the mandatory EIA list, the proponent is required to perform a scoping procedure and draw up terms of reference (ToR) that provide specific guidelines for undertaking the EIA study. The scoping results will include, but will not be limited to, the following aspects: the purpose of the ToR, description of the project and identification of the project's proponent, specific background objectives for the project, existing environmental conditions, proposed project activities, social analysis of the project's alternatives, identification of environmental impacts, proposed mitigation measures, social analysis, possible information gaps, and conclusions and recommendations. The scoping review should also clearly identify how the affected community will be involved in the project formulation, e.g., via public meetings ("barazas"), questionnaires and direct interviews.

In Tanzania, if screening shows that the proposed project will have significant adverse environmental impacts, the proponent will be required to perform a scoping procedure, draw up ToR, and prepare a written report on the results of the scoping exercise. This report will serve as a record for interested and affected parties and as guidelines for the EIA. At a minimum the report should indicate how scoping was undertaken; how the public was involved; how the authorities, and interested and affected parties were consulted, including dates and summaries of issues raised; alternatives to be examined in the impact assessment; the main issues of concern; and the specific guidelines for undertaking and preparing the EIA.

Following identification of key environmental issues of concern and how various stakeholders will be involved, the proponent will draw up the ToR for the EIA. The ToR must indicate that the Environmental Impact Statement will include: a description of the proposed undertaking and analysis of the need/ reason for the undertaking; objective of the undertaking; other options for carrying out the undertaking; alternatives to the undertaking; description of the existing environment that will be directly or indirectly affected; description of the future 
environment, predicting its probable status were the undertaking not to take place; environmental impacts that the undertaking may cause; proposed measures to prevent or mitigate all adverse environmental impacts; evaluation of opportunities and constraints to the environment as a result of the undertaking; a proposal for an environmental management programme to cover the construction, operation and decommissioning stages of the undertaking; a proposal for environmental monitoring; a proposal for a public information programme. At the end of the scoping procedure, the ToR and the scoping report must be submitted to NEMC for approval. When necessary, an inspection visit to the site(s) will be made.

In Mozambique, a Study of Environmental Pre-viability and Definition of Scope (EPDA) is obligatory for all Category A activities. The EPDA report should contain the following information:

1) Non-technical summary identifying the main issues, conclusions and proposals;

2) Identification and address of the proponent, as well as the details of the multi-subject team responsible for drawing up the EIR;

3) Limits of the area of indirect influence of the activity and patterns of land use in the area of direct and indirect influence;

4) Description of the activity and different actions foreseen therein, as well as the options to mitigate environmental impacts during the planning, construction, and operation stages and, for a temporary activity, decommissioning;

5) Bio-physical and socio-economic description of the site;

6) Identification and assessment of critical issues of the activity;

7) Indication of the potential environmental impacts of the activity;

8) Identification and description of aspects to be investigated in detail during the EIR.

In South Africa, a scoping will be drawn up for all activities identified under Listing Note $2 \mathrm{n} .^{\circ}$ R387. The Scoping Report (including the Plan of Study for the EIA) must include a description of the proposed activity and feasible and reasonable alternatives; a description of the property and the environment that may be affected and the manner in which the biological, social, economic and cultural aspects of the environment may be impacted by the proposed activity; and a description of environmental issues and potential impacts, including cumulative impacts that have been identified, and details of the public participation process undertaken. In addition, the Scoping Report must contain a roadmap for the EIA, referred to as the Plan of Study for the EIA, specifying the methodology to be used to assess the potential impacts, and the specialists or specialist reports that are required.

\section{Review}

The most important quality control feature within an EIA is the review stage as it helps to ensure that information concerning the environmental impacts of an action or project is adequate prior to its use in decision-making. Therefore, it is particularly important that this stage is carried out as effectively and efficiently 
as possible. Various methods to ensure objectivity of the review phase can be used. These include "use of review criteria, accreditation of EIA report review consultants, setting up of an independent review body, publication of the results of the review and involvement of consultees and the public" [5]. An independent institutional location for the EIA review function enhances EIA effectiveness. Each of the five African EIA systems reviewed here requires use of one or more of these methods to ensure objectivity in its review process.

In Kenya, the National Environmental Management Authority (NEMA) reviews EIAs. The ToR includes a checklist for lead agencies for review of an EIA Study report.

In Tanzania, a multi-disciplinary Technical Review Committee assists NEMC in the review process. The EIA regulations include review criteria (Article 24). NEMC has also issued Review and Monitoring Guidelines. The Council reviews an EIS in accordance with the following broad criteria areas: 1) description of the development and local economic baseline conditions; 2) identification and evaluation of key impacts (including residual and cumulative impacts) and their magnitude and significance; 3) alternatives, mitigating factors, environmental management plans, and commitment; and 4) stakeholders' participation and communication of results (including the non-technical summary).

In Mozambique, the Technical Assessment Commission uses the EPDA and ToR to review the EPDA report, EIR, and SER, respectively. The MCEA designates the Technical Assessment Commission. The same Commission that assesses the EPDA will review the EIR. The Provincial Directorate for the Environmental Coordination Affairs will nominate the Commission to review the SER. The EIA legislation includes provisions on the constitution of the Commission, which always comprises an uneven number of members.

In South Africa, several steps in the EIA procedure require reviews (Plan of Study for Scoping, Scoping Report, Plan of Study for EIA, EIR). The competent authority is responsible for review of the Plan of Study for Scoping and also the Plan of Study for EIA. In other cases, reviews may be carried out by the competent authority and specialists.

In Angola, there is no EIA review criteria established under legislation. However, technicians from the Ministry of the Environment/National Directorate for Prevention and Assessment of Environmental Impacts and/or external experts have carried out EIA reviews.

\section{Public participation}

Public consultation must be a two-way process, whereby information about the proposal is disseminated, and useful local information and opinions received. The consultation process should record the community's fears, interests and aspirations in order for these to be addressed in the EIA study. All the EIA systems reviewed here require public participation before or during the review stage. However, only in Tanzania, South Africa and Mozambique is public consultation mandatory during the scoping process. The proponent, in Tanzania and in Mozambique or the EAP in South Africa, must establish a list of interest- 
ed and affected parties and develop methods for notifying them about the proposal.

\section{$E M P s$, mitigation and monitoring of impacts}

In addition to predictions about the environmental impacts of a project, an EIA report generally includes proposals and recommendations for their mitigation and management. An EMP, which is generally prepared as part of the EIR, includes mitigation and monitoring measures to be undertaken by the proponent. All five African jurisdictions require that an EMP to be drawn up.

In Kenya and Tanzania, the EIA study report and Environmental Impact Statement, respectively, must incorporate an EMP proposing measures to eliminate, minimize, or mitigate adverse environmental impacts, including the respective cost, time frame, and responsibility for implementing the recommended measures. In Mozambique, the EIR and SER must incorporate an EMP, including monitoring of impacts, an environmental education programme, and contingency plans for accidents. In Angola, Decree no. 51/2004 [20] requires that a supervision and monitoring programme of the positive and negative impacts be drawn up.

In South Africa, the EMP must include:

1) details, including relevant qualifications, of the person who drew up the EMP;

2) proposed environmental management or mitigation measures identified in the EIA report, including those in respect of planning and design, pre-construction and construction activities, operation or undertaking of the activity and rehabilitation;

3) a detailed description of the aspects of the activity covered by the draft EMP;

4) identification of whom will be responsible for implementation of the measures;

5) where appropriate, deadlines for implementation of the measures; and

6) proposed mechanisms for monitoring compliance with the Environmental Management System and reporting thereof.

All the EIA systems reviewed here include a general requirement for mitigating impacts and for impact monitoring. Additionally, under the EU EIA Directive, monitoring should determine the accuracy of the original predictions, possible reasons for any deviations, the degree of deviation from predictions, and the extent to which mitigation measures have achieved their objectives.

\subsection{Foundation Measure of Performance}

Table 2 summarizes the performance of the six EIA systems against foundation evaluation criteria. Three foundation performance criteria are particularly noteworthy for this review: the existence of EIA guidelines, monitoring, and training.

The use of EIA guidelines is widely advocated and many international examples exist. Of the five African systems reviewed here, only the Angolan lacks developed guidelines. In Kenya, the general and specific EIA guidelines are set out 
in the Third Schedule of the Environmental (Impact Assessment and Audit) Regulations of 2003. In Mozambique, the MCEA has issued general guidelines for drawing up environmental impact studies and public participation. Tanzanian EIA legislation includes several guidelines. In addition to a General Checklist of Environmental Characteristics, NEMC has issued guidelines on general environmental impact assessment and procedure; screening and scoping; report writing and requirements; and review and monitoring.

In South Africa, six national guidelines (Overview of Integrated Environmental Management, Criteria for Determining Alternatives in EIA, Cumulative Effects Assessment, Environmental Impact Reporting, Environmental Management Plan, Review in EIA), as well as provincial guidelines and manuals, establish parameters for EIA. In the EU, there are guidelines on EIS review, scoping and screening, as well as checklists for the scoping and screening processes.

Only in Angola and South Africa the monitoring of EIA system is not required in legislation. Nonetheless, such monitoring exist in the South Africa case, feedback from previous experience (around nine years) was taken into consideration when drawing up the new EIA regulation.

In Tanzania, Kenya and Mozambique although monitoring of EIA is a legal provision, there is no effectiveness of that procedure.

Expertise in universities, research institutes and private consultancy firms in EIA is widespread in the countries reviewed here. The training of EIA project managers, technical specialists and others involved in the EIA process is critical for improving the effectiveness of EIA and enhancing standard practices, even in mature EIA systems. NEMC, NEMA, MCEA, and the National Directorate for Prevention and Assessment of Environmental Impacts (Angola) have indicated that only a small number of training programmes are provided. There is a general consensus on the need for more training programmes to improve capacity in EIA practice and standards in these African countries.

\section{Discussion, Conclusion and Recommendations}

The evaluation of the performance of the EIA systems discussed above and presented in Table 1 and Table 2 indicates that no one system is superior to the others in terms of overall performance. The five African countries considered here are at a similar stage of development in their EIA systems. Although Angola, as a consequence of civil war, lacks practical experience, its framework is nevertheless similar to the others.

Several general conclusions can be drawn from this review, although the study suffered from some constrains and limitations: 1) difficulties assessing original EIA studies and their formal evaluation; 2) difficulties assessing some higher levels of the EIA administration; 3) constant changes in the institutional framework, particularly at the government level and the ministry responsible for the

${ }^{4}$ Actually, during the three moments of assessment of the institutional and legal framework, we can consider generally a "Ministry responsible for the Environment". The agencies responsible for EIA did not suffer significant changes nor did EIA systems. 
environment ${ }^{4}$.

These five African countries and the EU share a common EIA framework: screening, EIA study preparation, EIS preparation/review, public consultation, and monitoring. They all have formal provisions for EIA and specific legislation concerning its practice. These EIA laws and regulations define the administrative arrangements and roles of competent authorities in the EIA process. Each jurisdiction has identified a competent authority for overseeing the EIA process. In all countries, the EIA is initiated by the proponent. The EIA is carried out by registered experts in Kenya, Tanzania, Mozambique, and Angola (however, registration requirements are different in each country). In South Africa, the EIA study is conducted by a pre-qualified Environmental Assessment Practitioner, registered in accordance with specific procedures. The EU EIA Directive does not require that an EIA study be carried out by registered experts.

Informal methods of coordination between competent authorities responsible for managing the EIA process and other entities responsible for pollution control or planning exist in Kenya, Mozambique, Tanzania, South Africa, and Angola. In the case of the EU, this varies from country to country. However, in some cases, mandates and the relationships between several institutions are unclear. To improve the effectiveness of EIA, it is necessary to clarify the institutional framework and their roles and responsibilities in the EIA process.

Despite the robustness of these EIA regimes, there are measures that would enhance the effectiveness of the EIA framework and practice. For example, in Kenya, legal provisions for submitting the scoping report for public consultation would enhance integration of community concerns and interests in the EIA final study. This is also an issue in Angola where new EIA legislation is being prepared. According to information received by the authors, public consultation during the scoping phase will be a formal requirement. In general, enhanced public consultation in these EIA systems faces several challenges, including, financial issues; education; cultural, gender, and political differences; and the decision-making culture. Similarly, public access to EIA reports and documentation is critical to ensuring objectivity during the review process. This information is not generally accessible to the public in these countries. South Africa and Tanzania are, however, taking the first steps to making this information available to the public. A further component that requires these governments' attention is EIA system monitoring. Financial issues, insufficient qualified personnel, and an increasing number of EIA applications undermine the capacity of competent authorities to adequately monitor these EIA systems.

It is clear that the procedures in the five African countries are complex and may, in fact, be more difficult to implement than those in the EU. For example, the EIA study report in Kenya and Tanzania must include measures to prevent health hazards, ensure employee safety in the work environment, and for emergency management. Training of EIA project managers, technical specialists and others involved in the EIA process is thus an essential element of these African countries EIA systems. Enhancing capacity in EIA will ensure these EIA systems 
to operate effectively and improve standard practices by incorporating experience and lessons learned.

Considering these findings, main recommendations to improve the EIA systems would be mainly to: 1) clarify and simplify the mandates of the several institutions involved in EIA process and system; 2) reinforce the capacity building action regarding the qualification of personnel involved in EIA systems; 3) improve and enlarge public access to EIA reports, including electronic means, also as a facilitator of the process of public consultation-this would constitute a balance facing the tendency to "political approval.

EIA is both a planning and a decision-making tool and helps ensure that development projects do not have costly impacts on the environment and communities. However, EIAs can have little impact on decision making if the process is primarily focused on outputs. In general, an EIA acts as a mitigation exercise because the option of halting projects is rarely considered. This is especially the case when projects are considered to have national, political, or strategic importance. In these African countries, economic development and its accompanying activities and projects make this a particularly urgent issue to consider. As Katima (2003) [22] noted, an effective and sustainable EIA regime is dependent, amongst other factors, on political will.

The African countries reviewed here have adopted EIA and integrated EIA systems into public policy despite the constraints they face. They have put in place significant EIA legal frameworks and procedures. As they continue to gain experience in EIA and to revise their EIA systems, they are moving towards a more flexible system with greater public involvement and robust arrangements and practices. It can be expected that ultimately EIA will help these countries meet their development priorities and socio-economic needs.

\section{Disclosure Statement}

The authors do not have any disclosure statement to proceed. All the authors have approved the final article.

\section{Fundings}

This study was carried out under the EU Project "PUMPSEA: Periurban mangrove forests as filters and potential phytoremediators of domestic sewages in East Africa", EU Contract no. 510863, funded by the Sixth Framework Programme of the European Commission. European Commission was not involved in study design; in the collection, analysis and interpretation of data; in the writing of the report; and in the decision to submit the paper for publication.

The publication was supported by the Portuguese Fundação para a Ciência e Tecnologia (FCT) through the UID/MAR/04292/2013.

\section{References}

[1] Economic Commission for Africa (ECA) (2005) Review of the Application of Environmental Impact Assessment in Selected Africa Countries. Addis Ababa, Ethiopia. 
[2] Directive 85/337/EEC on the Assessment of the Effects of Certain Public and Private Projects on the Environment. O.J. No 175 L, 14/03/97, p. 40.

[3] Directive 97/11/EC Amending Directive 85/337/EEC on the Assessment of the Effects of Certain Public and Private Projects on the Environment. O.J. No $73 \mathrm{~L}$, 14/03/97, p. 5.

[4] UNEP (2004) Environmental Impact Assessment and Strategic Environmental Assessment: Towards an Integrated Approach.

[5] Balsam, A. and Wood, C. (2002) A Comparative Evaluation of the EIA Systems in Egypt, Turkey and Tunisia. Environmental Impact Assessment Review, 22, 213-234. https://doi.org/10.1016/S0195-9255(02)00004-5

[6] Wood, C. (2003) Environmental Impact Assessment: A Comparative Review. 2nd Edition, Longman, Harlow.

[7] Leu, W.S., Williams, W.P. and Bark, A.W. (1997) Evaluation of Environmental Impact Assessment in Three Southeast Asian Nations. Project Appraisal, 12, 89-100. https://doi.org/10.1080/02688867.1997.9727045

[8] The Environmental Management and Co-Ordination Act, Kenya, 1999.

[9] The Environmental (Impact Assessment and Audit) Regulations, Kenya, 2002.

[10] Institute of Resource Assessment (IRA) (1998) The Performance of EIA in Tanzania: An Assessment. IRA Research Paper no. 41, University of Dar es Salaam, Tanzania.

[11] The Environmental Management Act (2004) Gazette of the United Republic of Tanzania, No. 6, Vol. 86, Dated 11 February 2005.

[12] The Environmental (Registration of Environmental Experts) Regulations, 2005. Government Notice No. 348 Published on 4 November 2005, United Republic of Tanzania.

[13] Decreto-Lei No. 5/98, Diário da República, I Série, No. 27, Angola, 1998.

[14] Decreto-Lei No. 45/2004, Boletim da República, I Série, Número 39, Mozambique, 2004.

[15] Decreto-Lei No. 42/2008, Boletim da Republica, I Série, Mozambique, 2008.

[16] Duthie, A. (2001) A Review of Provincial Environmental Impact Assessment Administrative Capacity in South Africa. Impact Assessment and Project Appraisal, 19, 215-222. https://doi.org/10.3152/147154601781767032

[17] DEAT. Overview of Integrated Environmental Management, Integrated Environmental Management, Information Series 0, Department of Environmental Affairs and Tourism (DEAT), Pretoria, 2004e.

[18] DEAT. National Environmental Management Act No. 107 of 1998; 1998c.

[19] DEAT. Review in Environmental Impact Assessment, Integrated Environmental Management, Information Series 13, Department of Environmental Affairs and Tourism (DEAT), Pretoria, 2004f.

[20] Decreto-Lei No. 51/04, Diário da República, I Série, No. 59, Angola, 2004.

[21] Decreto-Lei No. 59/07, Diário da República, I Série, No. 84, Angola, 2007.

[22] Katima, J. (2003) Environmental Impact Assessment: For Whose Needs? In UNEP EIA Training Resource Manual: Case Studies from Developing Countries. 
Submit or recommend next manuscript to SCIRP and we will provide best service for you:

Accepting pre-submission inquiries through Email, Facebook, LinkedIn, Twitter, etc. A wide selection of journals (inclusive of 9 subjects, more than 200 journals)

Providing 24-hour high-quality service

User-friendly online submission system

Fair and swift peer-review system

Efficient typesetting and proofreading procedure

Display of the result of downloads and visits, as well as the number of cited articles Maximum dissemination of your research work

Submit your manuscript at: http://papersubmission.scirp.org/

Or contact jep@scirp.org 